University of Rhode Island

DigitalCommons@URI

Open Access Master's Theses

1975

\title{
Delineation of Coastal Zone Management Units Using Ecological and Legal Criteria: The Caseof Atlantic Canada
}

Henry Paul Anderson

University of Rhode Island

Follow this and additional works at: https://digitalcommons.uri.edu/theses

\section{Recommended Citation}

Anderson, Henry Paul, "Delineation of Coastal Zone Management Units Using Ecological and Legal Criteria: The Caseof Atlantic Canada" (1975). Open Access Master's Theses. Paper 1165.

https://digitalcommons.uri.edu/theses/1165

This Thesis is brought to you for free and open access by DigitalCommons@URI. It has been accepted for inclusion in Open Access Master's Theses by an authorized administrator of DigitalCommons@URI. For more information, please contact digitalcommons-group@uri.edu. 
DELINEATION OF COASTAL ZONE MANAGEMENT UNITS USING ECOLOGICAL AND LEGAL CRITERIA: THE CASE OF ATLANTIC CANADA

BY

HENRY PAUL ANDERSON

A THESIS SUBMITTED IN PARTIAL FULFILIMENT OF THE REQUIREMENTS FOR THE DEGREE OF MASTER OF ARTS IN GEOGRAPHY

UNIVERSITY OF RHODE ISLAND 1975 
MASTER OF ARTS THESIS

of

HENRY PAUL ANDERSON

Approved:

Thesis Committee:

Major Professor

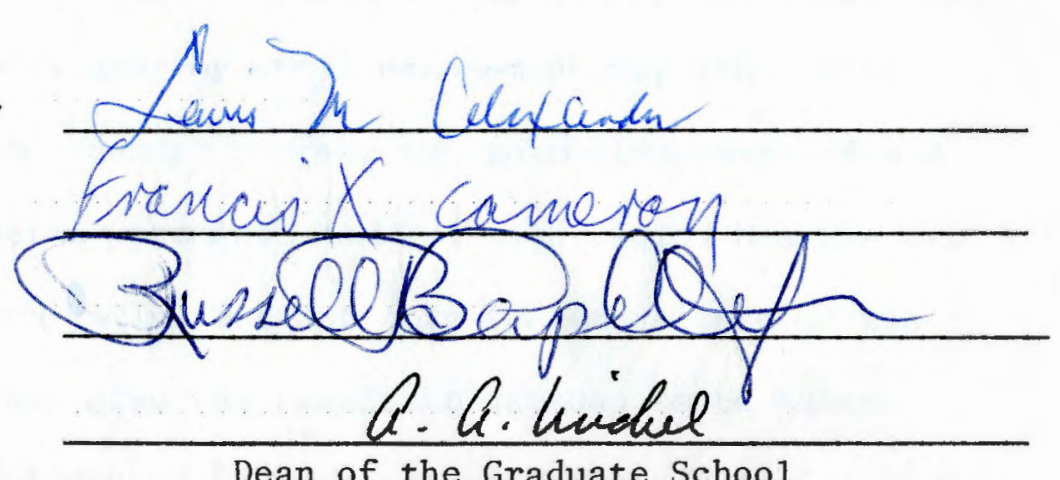

UNIVERSITY OF RHODE ISLAND

1975 
The coastal zone is an area that has inspired man to some of his loftiest achievements and has provided an environment suited to many uses. Unfortunately, the growing pace and scale of development have created irrevocable disturbances of a natural environment important to the welfare of man. Environmental management is presented as the action essential to secure future benefits by reducing and preventing harmful effects of utilization. Water was chosen as the focus of the management program because of the role it plays in the coastal zone, its past history of management, and its interdependency with adjacent land uses from which total environmental management may inherently evolve. Basic to this management process was acknowledgement of and adherence to the 'situation' premise, namely, each region has its own particular identity which influences not only the importance of the various considerations but also the resultant actions to be taken. Management is implemented through administrative agencies whose first priority is to establish designated areas of jurisdiction. If there were no constraints such as political boundaries and problems of political feasibility, what.shape would these administrative units take? What are the ideal spatial units and what compromises will have to be employed given the 'situation'? These units were thought best conceived through legal and ecological considerations as they give notice to the 'situation' as well as being scope oriented. Their application to the spatial delineation of the coastal zone management unit was the purpose of the study. Ecological considerations exemplify the complexity and fragility of the coastal zone, define the role man plays in the scheme of things (something that has been paid little attention by 
managers), and serve as an introduction to systems management having spatial connotations. Legal considerations not only define the area of jurisdictional authority but also the administrative capabilities.

Chapter 2 reviews the ecological considerations by focusing on man's role in nature, and the systems outlook from which the application of two natural ecosystems in spatial delineation of the management area may be justifiably proposed.

Acknowledgment of the ecological 'situation', which incorporates the laws of nature, ideally should be complacent with international and national law which provides not only the jurisdictional authority to act but also the power to restrict what might be considered the appropriate action. This was carried out in Chapter 3 as it delved into legal norms as well as speculation of future developments in this field.

The river watershed and coastal ocean as designated by the ecological considerations were found from a legal point of view to require political compromise and alternatives. Integrated management requiring cooperative federalism had to be utilized in the application of the watershed concept. This was felt to be politically reasonable and therefore attainable. The coastal ocean, given present international legal norms, could not be included; therefore, a viable alternative was required. At the present time this alternative was the management of the coastal ocean within the coastal states' territorial sea with some initiatives being taken toward ocean management or at least toward coastal ocean management by international or national agencies. The thesis concludes in Chapter 4 with a real world application of this hypothesis for Atlantic Canada (made possible by the allusion throughout the thesis to the Canadian 'situation' as it served to illus- 
trate the considerations). The only logical conclusion being that as the 'situation' differs from region to region so will the applicability of the concept. 
INTRODUCTION . . . . . . . . . . . . . . . . . I

I. MANAGEMENT . . . . . . . . . . . . . . . . 4

Management Philosophy .............. 4

Management strategy . . . . . . . . . 5

Scope . . . . . . . . . . . . . . . . 8

Summary . . . . . . . . . . . . . . 15

II. ECOLOGICAL CONSIDERATIONS . . . . . . . . . . 17

Man in Nature................ 17

The Systems outlook . . . . . . . . . . 21

Application of the Systems Outlook . . . . . . 24

III. LEGAL-POLITICAL CONSIDERATIONS . . . . . . . . 30

Jurisdictional Authority--Domestic . . . . . . 31

Jurisdictional Authority--International . . . . . 44

IV, THE ECOLOGICAL-LEGAL CONCEPT AS APPLIED TO COASTAL

ZONE MANAGEMENT AUTHORITY DELINEATION--CONCLUDING

REMARKS . . . . . . . . . . . . . . . 59

Synopsis . . . . . . . . . . . . . . 59

Implementation in Atlantic Canada . . . . . . 61

Applicability of the Concept . . . . . . . 64

Conclusion ................. 66 


\section{IIST OF ILLUSTRATIONS}

Figure

Page

1. Water Cycle . . . . . . . . . . . . 7

2. Sketch of Coastal zone and Shore Zone Definitions . . 12

3. Coastal Zone Workshop's Coastal Zone . . . . . . 14

4. Water, Water Everywhere . . . . . . . . . . 18

5. Land-Sea Interrelationships . . . . . . . . . 27

6. Map 1--Activity Scope ............. . Pocket

7. Map 2--Coastal Zone Management Boundaries . . . . Pocket 


\section{LIST OF TABLES}

Table

Page

1. An Environmental Management Matrix . . . . . . 32

2. Labyrinthine Complexity of Authority . . . . . . 45

3. Enabling Legislation . . . . . . . . . . 46 


\section{INTRODUCTION}

An important part of the Canadian environment is the narrow strip of land and water around our coasts. A resource of the first order, this coastal zone is experiencing increasing pressures from many uses. It is capable of yielding a continuing stream of aesthetic, recreational, and commercial benefits--providing the harmful effects of many uses are reduced or prevented. To secure these future benefits society must recognize and understand the dynamic nature of the coastal environment and the vulnerability of its intrinsic qualities. At present, the growing pace and scale of development, the undesirable acceleration of natural processes, and the irrevocable disturbance of valuable habitats are all cause for concern. 1

It is at the shoreline where the lithosphere, hydrosphere, and atmosphere converge to form the triple interface that gives the coastal zone uniqueness as a geographical concept. It is an area that has inspired man to some of his loftiest achievements and has provided an environment suited to many uses.

The coast of the United States is, in many respects, the Nation's most valuable geographic feature. It is at the juncture of the land and sea that the greater part of this Nation's trade and industry take place. The waters off the shore are among the most biologically productive regions of the Nation. ${ }^{2}$

What has been the cause of so much of man's efforts being funnelled into this area? In the past, the coast frontiered an undiscovered and undeveloped land mass. Today, the converse is true; the coast is the margin of all lands and the frontier of all oceans.

For human beings, who are land animals, the simple presence of

${ }^{1}$ L. Edgeworth, Assistant Deputy Minister, Environment Canada.

${ }^{2}$ Commission on Marine Science, Engineering, and Resources, our Nation and the Sea. (Washington: U.S. Government Printing Office, 1968) p. 49 . 
an expanse of water makes the coastal zone unique and thus an attractive place to live and visit. Sigmund Freud calls it "that oceanic feeling" when man desires to be by the water, representing a sort of genetic going-home-again. Microbiologist Rene Dubois in So Human An Animal observes that water is of interest to man because it is one of those natural influences "that have shaped life and thereby created deep human needs. The pathetic weekend exodus to the country and beaches...testifies to the persistence in man of biological and emotional hungers that developed during his evolutionary past, and that he cannot outgrow." 3 The fact remains above all that man is inseparable from water, not merely because it is essential to life but because somehow "it speaks to him in a language that is soothing and universal".

Whatever the reasons for man's utilization of the coastal zone, permanent and seasonal use increases as each year goes by. The Coastal Zone Workshop held at Woods Hole, Mass., in 1972 divided man's uses of the coastal zone into six major categories. 4

1. Living space and recreation. This is the source of a great deal of pressure on the coastal zone.

2. Industrial and commercial activities. Power production, mining, commercial development, and fishing are just a few of these activities.

3. Waste disposal. Man uses the coastal zone to dump both industrial and domestic wastes.

4. Food production. This is largely fishing, but a promising future use involves aquaculture.

5. Natural preserves.

${ }^{3}$ Rene Dubois, So Human An Animal. (New York: C. Scribner and Sons, 1968) $\mathrm{p}$.

4 Bostwick H. Ketchum, ed. The Water's Edge. (Cambridge: MIT Press, 1972) p. 13. 
6. Special government uses. This is a proportionately small area of the coastal zone which includes military and coast guard installations, NASA bases, and government parks and lands.

These uses result in the increasing pressures and harmful effects mentioned by Mr. Edgeworth as requiring action.

The purpose of this thesis is to identify strategies that governments might employ in order to respond to environmental problems. Environmental management is the action required to secure future benefits by reducing and preventing harmful effects of utilization. In this particular case, a concept promoting the spatial aspects of environmental management is derived; it provides the framework within which coastal zone areas in Atlantic Canada can be administered.

Before going on to the next section we should clarify the connotation of the term "environment". We are concerned with the physicalnatural environment primarily because this is the habitat of man and of the millions of plant and animal species with which he shares spaceship Earth. Deterioration and disruption of this environment threatens man and the complex ecosystem upon which he depends and of which he is part. Because of the role that man plays in the physical-natural environment we will also become concerned with the social-political environment of man as it becomes involved with, and affects, the former. 


\section{MANAGEMENT}

\section{Management Philosophy}

The preparation of environmental management policies for the benefit of areas of concern must take into consideration current legislation, present and anticipated utilization, the character of the political-social-economic system, and most importantly the capacity of the area to assimilate man-induced utilization. The premise here is that each region has its own particular identity which influences not only the importance of the various considerations but also the type of management program to be implemented. This concept the author simply refers to as the 'situation', for if management is to be relative and effective, the 'situation' must be known.

We have mentioned it, but yet have failed to say what is meant when we speak of environmental management of the coastal zone. In our context it is taken as the administration of the natural and man-made environments by being responsive to the regional 'situation' and encompassing :

1. land-based activities

2. marine-based activities

3. conflict management--this covers environmental problems that result from the interaction of two or more activities, whether similar or dissimilar, having environmental consequences.

Our objective is the resolution of present conflicts and prevention of future conflicts among spatially distributed phenomena. The management 
yol sought is the optimal sustained use of coastal resources consistent vith the retention of the natural ecosystem and amenities of the coastal zone. In order to strive for symbiotic relationships, neither the complete destruction of the natural environment nor complete prohibition of development and exploitation are acceptable alternatives.

Having established this basis of orientation, let us now turn to our management strategy.

\section{Management Strategy}

The basic assumption in our strategy is that initial management of one resource component of the coastal zone will evolve into total environmental management. The component in our case is water, both fresh and salt, for the following reasons. First of all, a review of management programs presently being carried out reveals an initial focus on water management in the field of resource administration. The reasons for such an initial focus include:

1. Water is most adaptable to public management on a large scale.

2. It is the most viable of all resource systems.

3. Water management allowed man to cope in a rigorous way with integrated management of linked resources in the same area.

Secondly and perhaps most importantly, integrated management is possible after the groundwork for management is developed and after the most critical natural resource of the coastal zone, water, is under management.

A number of organizational problems arise as a result of the natural characteristics of water. Let us deal with the first two briefly since it is the third which brings us into our problem area. The first characteristic is that water, in contrast to other resources, is looked 
upon as a 'common property resource' free for all to use at their own discretion. This 'community vocation' as confirmed by the law, dictates a public sector responsibility for water management. A second characteristic, frequent and almost simultaneous utilization, calls for a determination of allocations and priorities among the competitive uses. In other words the multifunctional aspect calls for administration of water uses rather than of the water itself. The third characteristic is mobility; as a consequence, management must take into consideration the 'external effects' either in time (at a later date) and/or in space. Water forms a physical system (water cycle) whose balance is partially a function of the activities carried out in the environment. Thus water management problems arise from the relationships between the various activities and the water system, a system that is characterized by mobility and a free-flowing nature. The problem is to include as much as possible of the water cycle (Figure 1) within an administrative unit in order to be able to control as many of the variables as possible. The variables in this case are the activities adversely affecting water quality.

The hydrologic system is closely inter-related with other physical systems composing the environment, as well as with the various human systems that affect it or are affected by it. Consequently, it is important to develop administrative tools which will help to co-ordinate administrative actions designed to influence the use of the environment. We must determine precisely what are the goals of environmental quality, what are the effects of policies relating to one resource on other resources, and how the various goals can be pursued harmoniously. 5

Although this approach should provide the foundation for eventual integrated management, first of all it is important to develop adminis-

${ }^{5}$ Richard W. Judy et al., Water Management Research: Social Science Priorities. (Ottawa: Queen's Printer, 1969) p. 122 . 


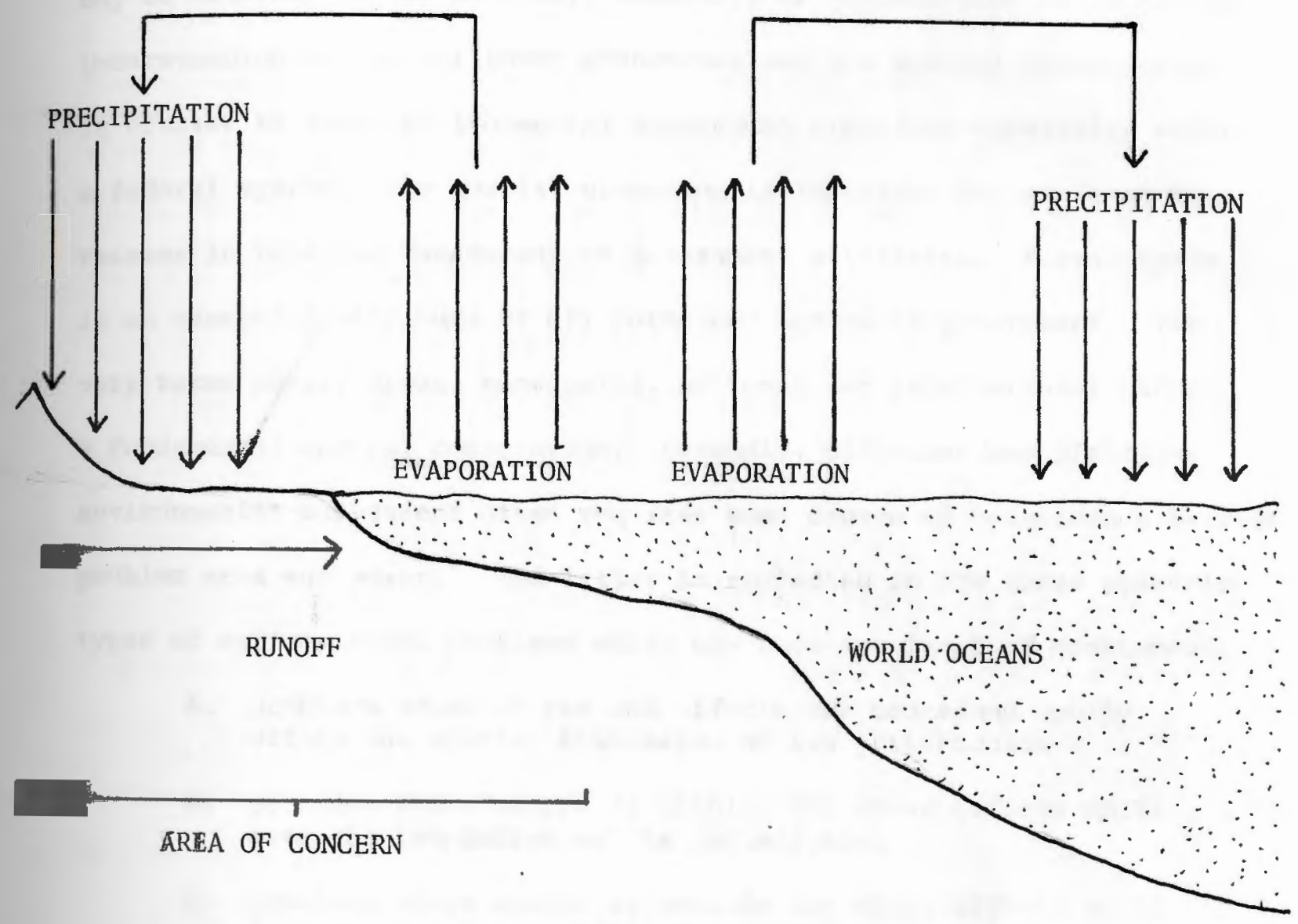

Fig. 1--Water Cycle 
trative tools which will help to co-ordinate administrative actions designed to influence the use of the environment.

Scope

The dynamic nature of water is conducive to spillover costs that may be external to the activity, industry, or jurisdiction responsible. Understanding of the spillover phenomenon and its spatial connotations is crucial to sound environmental management practices especially within a federal system. The spatial dimension is important for at least two reasons in relating management to government activities. First, space is an essential attribute of all forms and orders of government. The very terms rural, urban, provincial, national and international carry a fundamental spatial connotation. Secondly, efficient and effective environmental management often requires some degree of coincidence between problem area and power. ${ }^{6}$ The latter is reflected in the three possible types of environmental problems which may face any level of government.

A. problems whose source and effects are contained wholly within the spatial boundaries of its jurisdiction

B. problems whose source is within, but whose effects spill over the boundaries of its jurisdiction

C. problems whose source is outside but whose effects spill into the boundaries of its jurisdiction

In response to the spillover phenomenon and the dynamic nature of water; definition of the coastal zone's spatial extent (hereafter referred to as scope), as described by landward, seaward, and lateral boundaries, is an initial consideration in the management of the coastal zones water resources. च

${ }^{6} \mathrm{~J}$. W. MacNeil, Environmental Management. (Ottawa: Information Canada, 1971) p. 18. 
This approach was also subscribed to by a recent report entitled Nowards Integrated Resource Management. It listed the "definition of areas for administrative implementation of integrated resource management on a rational basis" as the first of three major tasks in the implementation of resource management. 7

At the present time Canada has virtually no expertise in the coastal zone management concept which leaves us almost totally dependent upon the experience of others, especially management personnel in the United States. Their experience and expertise must be studied and evaluated in order that conclusions might be rational and valid in relation to the Canadian 'situation'.

Due to these circumstances the author turned to the U.S. experience in quest of any acceptable definition or standard procedure by which the scope of the coastal zone might be delineated. It was found that no generally agreed upon and acceptable definition existed with most limits equally ambiguous or arbitrary. ${ }^{8}$ The only alternative remaining was to review proposed definitions that might prove beneficial in the determination of criteria (standard procedures) for establishing the scope of new coastal zone regions.

The first definition considered was that of $\mathrm{Dr}$. Lewis M. Alexander who in 1968 identified the coastal zone as a fifty mile strip of land

${ }^{7}$ Sub-Committee on Multiple Use, Towards Integrated Resource Management. (Ottawa: Queen's Printer, 1969) p. 12 .

8 This conclusion was reached upon a review of $A$ Description and halysis of Coastal Zone and Shoreline Management Programs in the United states and the article "Status of State Coastal Zone Management Programs" by Armstrong and Bradley; and conversations with Dr. Lewis M. Alexander and Dr. Francis X. Cameron and other personnel at the University of Rhode Island. 
measured inland from the mean high water mark. "Similarily the region is taken as extending some fifty miles offshore--this distance being close to the average distance at which many shore-based activities take place such as recreational boating, sport fishing, or 'day-fishing' by commercial vessels." 9

A somewhat narrower and ambiguous viewpoint was presented by the Commission on Marine Science, Engineering and Resources. The seaward limit was the territorial sea of the United States while the landward boundary included all sites and activities dependent upon the seas. This landward extent was to be established by the individual coastal states concerned, with the lateral boundary automatically being the extension of the state's political boundary seaward to the edge of the territorial sea.

A whole range of definitions were presented in the various Bills of the House of Representatives and Senate. A consensus was reached as to the seaward boundary, that is the extent of the coastal state's territorial sea. Definition of the landward boundary ranged from the land in close proximity to the coastline (H. of R. Bills 14,730 and 14,731) to those lands extending inland to the landward extent of maritime influences (S. 2808) with maritime influence defined as "such amount of land running back from the high water mark which under contemplation of human and natural ecology may be considered to come under the direct and immediate influence of the adjacent sea or lake". 10

The lack of consensus resulted in this matter being left to the discretion of the coastal state as was borne out in the Coastal Zone

\footnotetext{
${ }^{9}$ Lewis M. Alexander, Marine Regions of the United States. p. 4. ${ }^{10}$ U.S., Congress, Senate, Bill s. 2808.
} 
Management Act of 1972 .

Coastal zone means the coastal waters (including the lands therein and thereunder) and the adjacent shorelands (including the waters therein and thereunder) strongly influenced by each other and in proximity to the shorelines of the several coastal states, and includes transitional and intertidal areas, salt marshes, wetlands, and beaches. The zone extends, in Great Lakes waters to the international boundary between the United States and Canada and, in other areas seaward to the outer limit of the United states territorial sea. The zone extends inland from the shorelines only to the extent necessary to control shorelands, the uses of which have a direct and significant impact on the coastal waters....II

Unfortunately, consideration of the natural environment has not been fully integrated into these definitions. It seems inconceivable that man could attempt to manage this component with little or no regard to its nature. Let us now look at a geologic definition of the coastal zone as this surely is one of the environment's component parts. ${ }^{12}$

The coastal zone was defined in such terms as the coastal plain, the continental shelf, and the waters that cover the shelf. The outer edge of the shelf was taken as the break in slope marking the change from the relatively horizontal shelf to the steeper continental slope. This break marks the topographical and structural edge of the continent and is the boundary between the relatively shallow water covering the shelf (coastal ocean) and the depths of the true ocean. Conventionally the 200 meter depth mark has been taken as the break-point or outer edge of the shelf although deviations do occur. This geologic definition of the coastal zone is depicted in Figure 2.

One important element is still missing in these definitions, that is a human and natural ecological viewpoint. This was realized by the

\section{1} Coastal Zone Management Act, 86 STAT. 1281.

12 D. L. Inman and C. E. Nordstrom, "On Tectonic and Morphologic Classification of Coasts" Journal of Geology (Vol. 79, No. 1) p. 6 . 


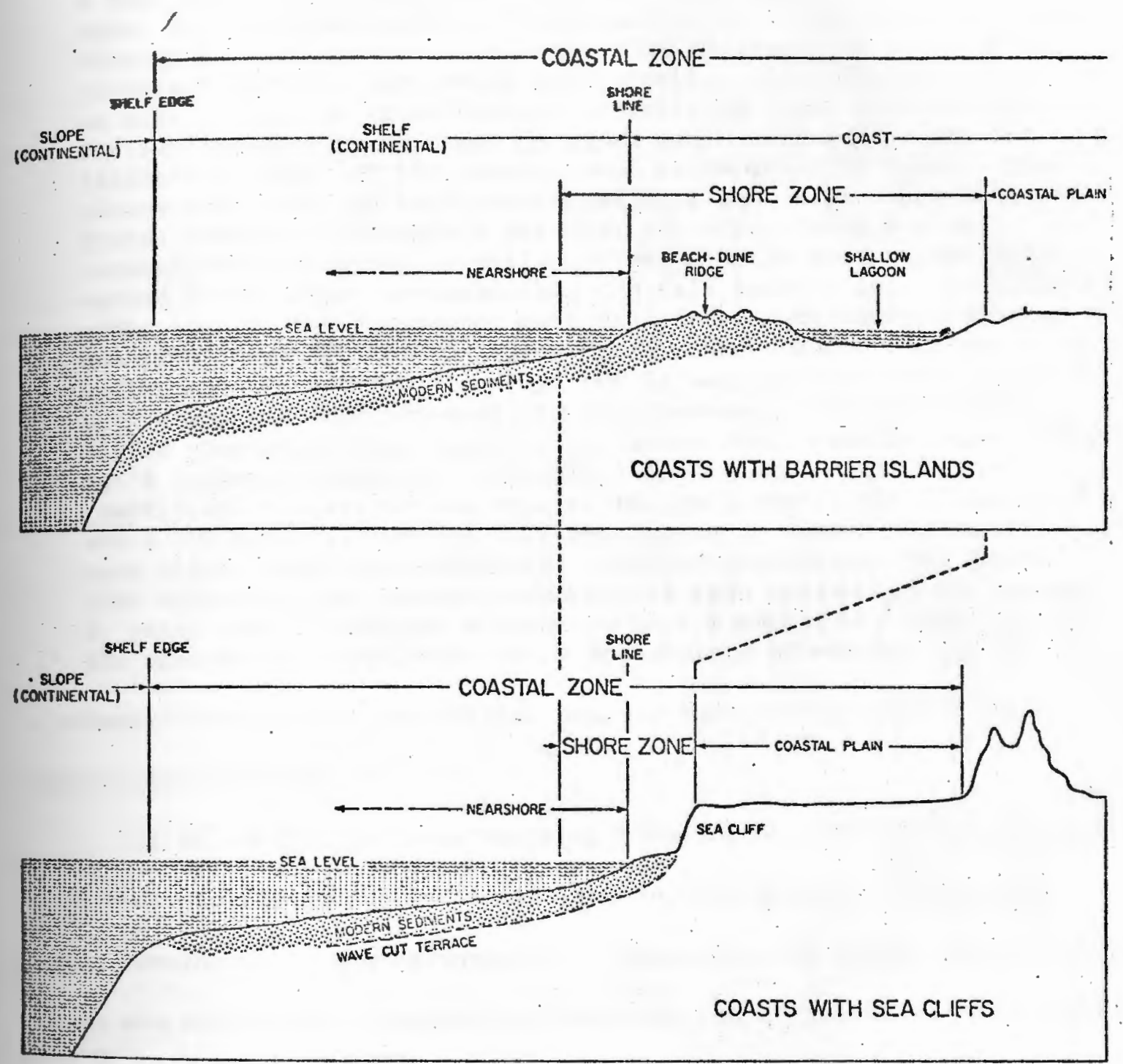

Fig. 2--Sketch of coastal zone and shore zone definitions (after Inman and Nordstrom, 1971) 
Coastal Zone Workshop at Woods Hole which adopted a working definition

combining demographic, functional and geographic considerations.

The coastal zone is the band of dry land and adjacent ocean space (water and submerged land) in which land ecology and use directly affect ocean space ecology, and vice versa. The coastal zone is a band of variable width which borders the continents, the inland seas, and the Great Lakes. Functionally, it is the broad interface between land and water where production, consumption and exchange processes occur at high rates of intensity. Ecologically, it is an area of dynamic bioeochemical activity but with limited capacity for supporting various forms of human use. Geographically, the landward boundary of the coastal zone is necessarily vague. The oceans may affect climate far inland from the sea. Ocean salt penetrates estuaries to various extents, depending largely upon geometry of the estuary and river flow, and the ocean tides may extend even farther upstream than the salt penetration. Pollutants added even to the freshwater part of a river ultimately reach the sea after passing through the estuary. The seaward boundary is easier to define scientifically, but it has been the cause of extensive political argument and disagreement. Coastal waters differ chemically from those of the open ocean, even in areas where man's impact is minimal. Generally, the coastal water can be identified at least to the edge of the continental shelf (depth of about 200 meters), but the influence of major rivers may extend many miles beyond this boundary. For the purposes of the coastal Zone Workshop, the seaward boundary has been defined as the extent to which man's landbased activities have a measurable influence on the chemistry of the water or on the ecology of marine life.13

A schematic diagram of the coastal zone as outlined by the Workshop is represented in Figure 3 .

It is the Coastal Zone Workshop's definition of the coastal zone that the author supports and" would like to see adopted. The problem still remains as to the delineation of scope and the selection of criteria which can perform this function effectively and efficiently. Many valid points as to the criteria for determination of the scope have come to light in these definitions. They include human ecology (social, economic and political considerations), legal status of international boundaries, ecological considerations, and geologic considerations to name just a

13 Press, 1972) p. 4. 


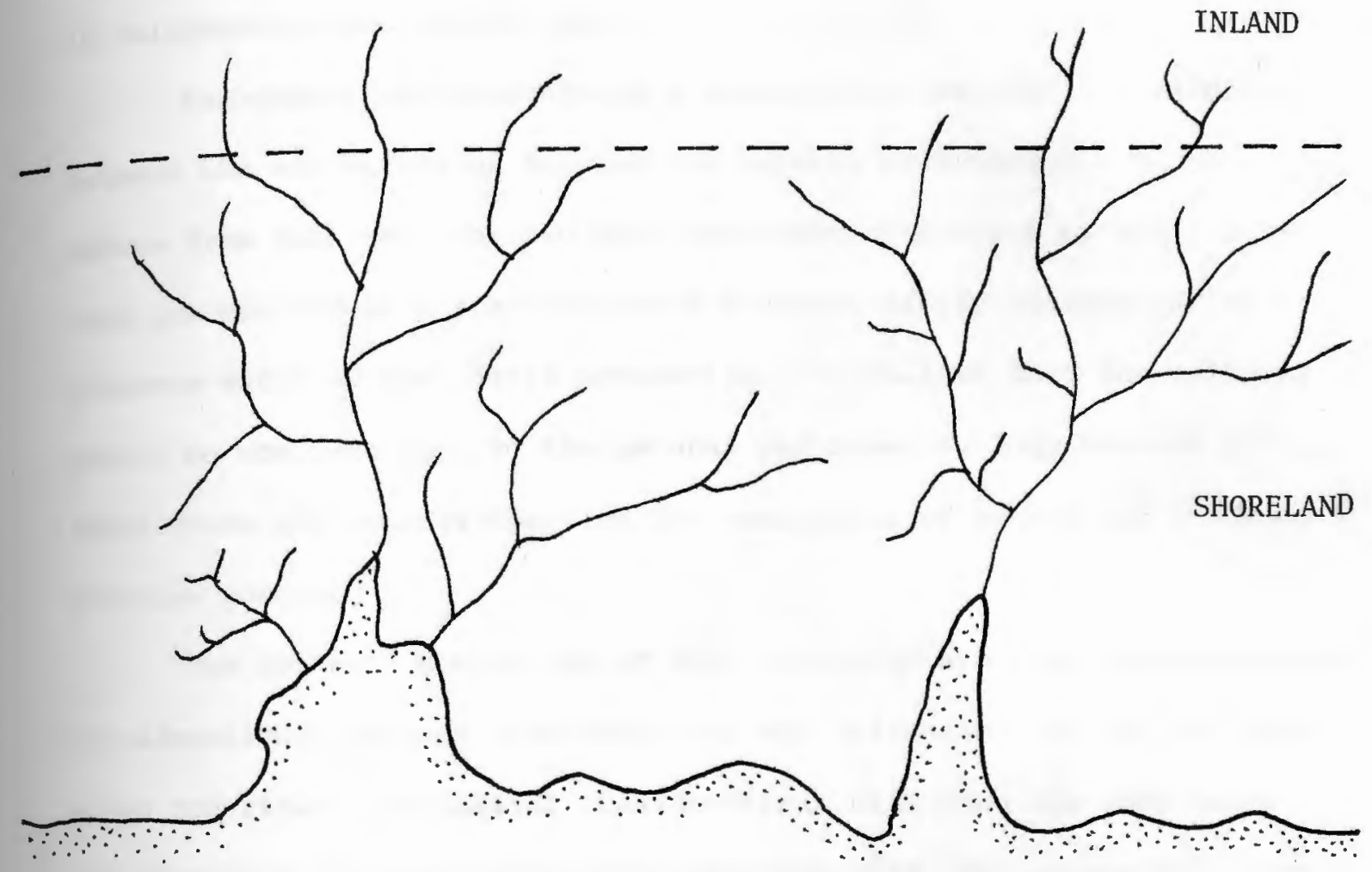

SHELF

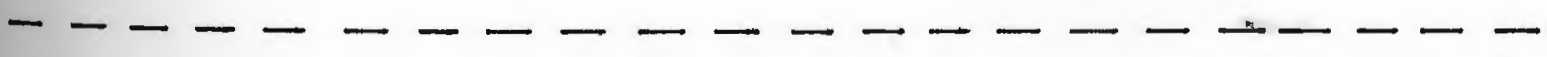

OPEN SEA

Fig。3--Coastal Zone Workshop's coastal zone. 
few. However, it would be impossible to employ all such criteria and therefore a value judgement must be made as to the criteria most suitable in delineating the coastal zone.

Management was proposed as a solution to the conflict existing between the activities of man and the natural environment. We can deduce from this that the two most important components of the coastal zone are man due to his activities and nature simply because of its presence which we feel needs protection. It follows that the criteria should be complementary to the natural and human ecology because of their roles and because they are the recipients of management's administrative powers.

The criteria coming out of such reasoning are legal and ecological considerations, as they give notice to the 'situation' as well as being scope conscious. Ecological considerations will make the complexity and fragility of the coastal zone understandable, define the role that man plays in the scheme of things, and serve as an introduction to the concept of systems management, the latter having spatial connotations. Legal considerations will not only dictate the area of jurisdictional authority but also the administrative capabilities with regards to the 'situation'.

Summary

The objective of our coastal zone management program is to resolve present conflicts and prevent future ones in order that symbiotic utilization of coastal resources might be achieved.

In order to carry out this objective we found that the management of one coastal zone resource from which total environmental management would eventually evolve was the logical and obvious initial consideration. 
Water was chosen as that resource for inherent and practical reasons. The initial consideration and focus of this thesis given these assumptions is the delineation of administrative units within which the management program could function. This involved a review of definitions of the coastal zone from political, biological, ecological, and geologic viewpoints; all to no avail as a standard procedure was not evident. The management concept was then reviewed to hypothesize on criteria for a standard procedure of delineation. The criteria chosen were ecological and legal considerations because of their representative and responsive character towards natural and man-made systems. 


\section{ECOLOGICAL CONSIDERATIONS}

One clear principle has emerged in ecology in recent years: the science of interrelationships between components and their environment connotes a dead end with unanswerable questions in respect to a single line of enquiry. Ecology dictates consideration of the whole, as it is the complex interactions that problems stem from. The only viable solution is a systems approach through ecosystem analysis which may also be applied to the delineation of scope. (Fig. 4)

\section{Man in Nature}

Today man can occupy an incredible variety of ecological niches without the necessity of any structural change in his body-the upper atmosphere without growing wings, the bottom of the sea without gills or fins, and most recently, outer space. We might conclude from this that man's technology has been superbly successful and that the environment is conquered. 14

To the contrary, the laissez-faire spirit of exploitation and the goal of economic growth has caused a dualism in contemporary society; monumental achievements beside astonishing omissions and misdirection is the cause of increased concern by members of our society. All economic development takes place within natural ecosystems, which may or may not have been already modified by man. Development brings along varying degrees of modification, but always remains subject to the ecological limitations which operate within natural ecosystems; these limiting factors must be taken into account if the development is to succeed. The problem today is that success has new connotations--in our

14 Source unknown. 


\section{WATER，WATER EVERYWHERE}

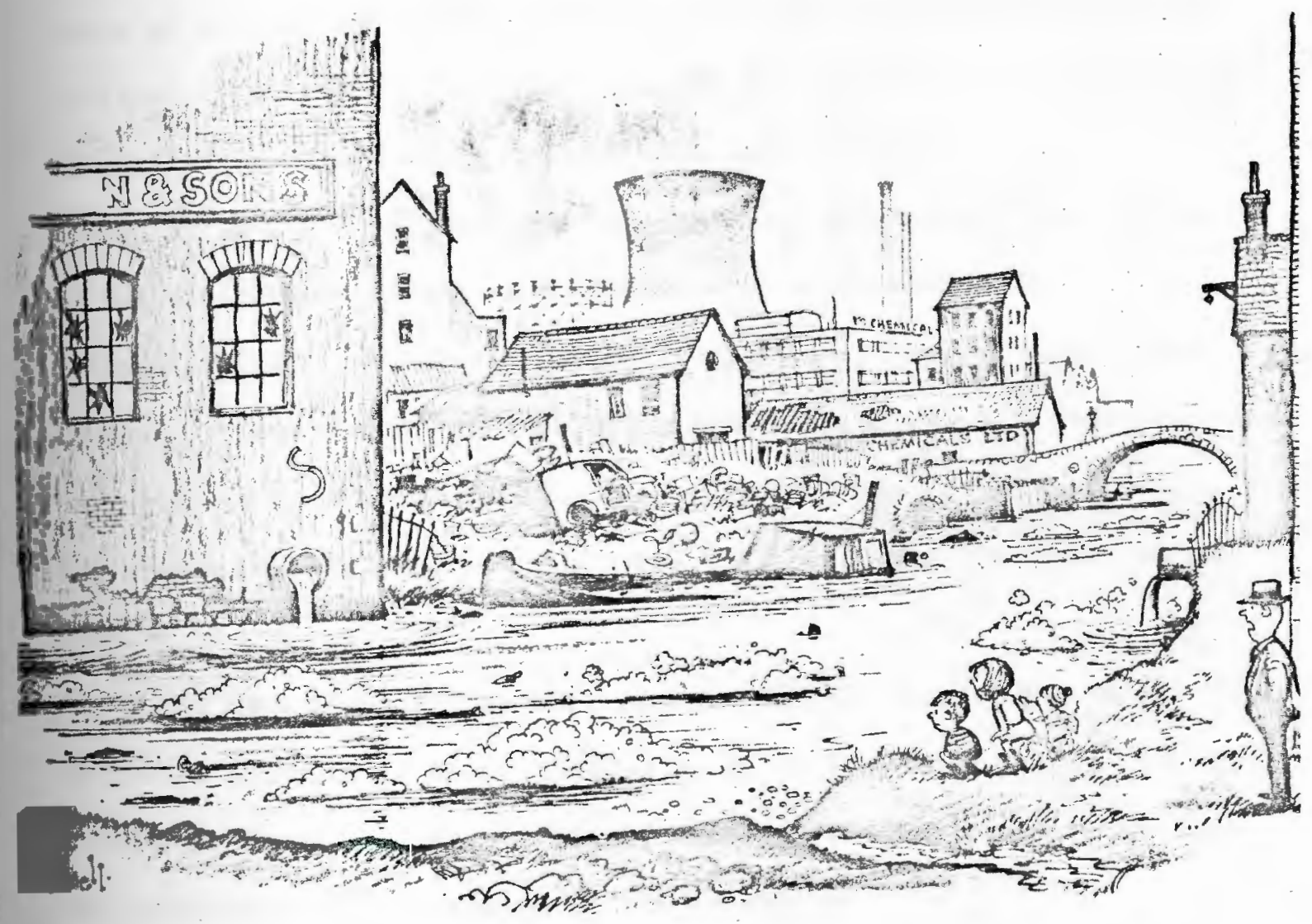

"They'll have to do something soon. It's affecting polar bears in the Arctic."

Fig. 4

(after The1we11, 1971) 
case creation of symbiotic relationships between development and the natural environment.

To understand and be able to manage the actions of man towards the environment, it is first necessary to view his place in nature. Modern day society tends to overlook the fact that man exists by virtue of a highly evolved and specialized environment. In short, man is dependent upon other organisms (and minerals) both for the immediate means of survival and for maintaining habitat conditions under which survival is possible. The role that the environment serves is not only threatened by depletion but also by disruption.

It is the disruption of the system as a result of the relegation of the environment by man to a position of subservience and nonrelatedness that has been the cause of the environmental crisis now upon us. "Ninety-five percent of man's technological achievements are estimated to have been made in the last twenty years. And pollution has been a serious problem in roughly this same time period...the connection is obvious...." 15

In summary, environmental management must acknowledge man's role in nature and this is best achieved by an ecological outlook. The precarious position man has put himself into in contradiction of ecological principles is illustrated by the following. 16

1. Law of the Inoptimum--"No species encounters in any given habitat the optimum conditions for all of its functions." Hence, man tends to modify his habitat to satisfy his shortrun environmental needs and desires. Further, man draws to

15 Ontario Department of Environment, Environmentally Yours. (Toronto: Queen's Printer, 1973) p. 4.

${ }^{16}$ Pierre Dansereau, "Ecological Impact and Human Ecology" Future ironments of North America. (Garden City, N.Y.: Natural History ress, 1966) pp. 459-460. 
given places many desired resources from elsewhere, affecting the distribution of materials, including wastes.

2. Law of Tolerance--"A species is confined, ecologically and geographically, by the extremes of environmental adversities that it can withstand." Modifications of environment by man have surpassed the tolerance of numerous species, and the extreme danger of course, is that man's tolerance may soon be exceeded and man will become extinct.

3. Law of Competition-Co-operation--"Organisms of one or more species occupying the same site over a given period of time, use (and frequently reuse) the same resources through various sharing processes which allow a greater portion to the most efficient." Man is always the most efficient, therein gets the greater portion of resources which all too often he pollutes to the point of exclusion of other species no matter their importance.

4. Law of Evolutionary Opportunity--"The present ecological success of a species is compounded of its geographical and ecological breadth, its population structure, and the nature of its harbouring communities." Consideration of man's opportunities seems slim in respect to its ecological breadth (narrow and specialized), its population structure (overpopulation), and the nature of its harbouring communities (cities).

5. "Changes and fluctuations in the environment (exploitation and competition, among others) represent selective pressures upon the population to which it must adjust. Those organisms that cannot adjust disappear, perhaps decreasing for a time the maturity of the ecosystem." Can modern society bring itself around to a point where it adjusts or adapts rather than overcomes or fixes?

6. "The ecosystem has historical aspects. The present is related to the past, and the future is related to the present." This should give added initiative to ecologize present-day actions.

7. "Everything is related to everything else." This has to be utmost on our minds when we decide to act.

These reflections serve as a grim reminder of man's situation and role in the ecosphere. In relating them to water management problems, we are led to ask the following questions. Can man continue to allow unprecedented and unchecked economic development (optimum conditions) yet maintain a balance by treating sewage and industrial wastes to the extent that rivers may once again assimilate rather than be polluted? Can man 
continue to tolerate the offshoots of polluted water? Will the contamination by mercury, DDT, etc. someday render man into a course of unstoppable self-destruction? Is man able to co-operate through symbiotic actions in order that beneficial organisms (e.g. fish) may survive? Above all can he realize the historical and systems nature of the world he lives in?

The problem is complicated daily as man, due to his diversification, forms new and major linkages with more of the environment either intentionally or inadvertently. A situation exists in which man's wellbeing is in direct correlation to the well-being of the environment and only the science of ecology acknowledges that relationship.

\section{The Systems Outlook}

Man in his process of visualization has found it convenient to narrow his viewpoint. Nature however, knows no such limitations or categories; it exists as an interacting whole. Comprehension of the systematic nature of the environment may however be achieved through systems ecology ${ }^{17}$ whose use of the ecosystem (the major ecological unit) incorporates fundamental relationships and linkages so long ignored. It therefore follows that we might not only be able to utilize the ecosystem concept in establishing the management program's scope; but also the bonus feature, namely inclusion of functional aspects later in the program as recognition is made of the functions that subsystems serve as well as complex suprasystems within which an ecosystem must exist. The systems approach therefore, can be a way of thinking about

17 Regardless of the hierarchical level examined, the ecosystem concept can be applied. The ecosystem is the basic unit of ecology which may be studied on any particular level by specifying a qualifying adjective. 
the job of environmental management.

It is men with...expanded views of reality who will exert the greatest influence on man's (environment). The views, insights, and attitudes that reflect understanding of these concepts are the qualities of systems thinking, and the guide to the systems approach...

A total system inevitably exists at the start. It is already there. Systems design, or (management) certainly deals with the whole to the extent that man's present knowledge permits him to do so; but the objective is to deal not only with the total system but also with its own internal subsystems and with its relationship to other systems. The idea is to (keep) the system that is the whole and its parts, in relationship to the external systems that constitute its environment. 18

The systems concept encourages due consideration that helps to resolve the complexity of the 'situation' as well as recognize the nature of the problem thereby facilitating work within the perceived environment. The concept is also imperative in order that administrators act accordingly and properly in respect to the 'situation'.

What is a system? A system is a set of objects together with relationships between the objects and between their attributes. The objects are the parts or components of a system which are unlimited in variety; the attributes are the properties of the objects; and the relationships are those ties that bring the system together.

There also exists a hierarchy of suprasystems, beginning with subsystems, systems, systems of systems, and so on. What then defines the system? A system lies in the eye of the beholder, for we can define a system in any number of ways according to our interests and purposes. Once we have defined our interests in terms of objects, attributes, and Klationships, we have defined the resolution level at which we are going to work. Other levels are not recognized simply because doing so

${ }^{18}$ John A. Beckett, Management Dynamics. (New York: McGraw-Hill, 1971) p. 106. 
has no meaning for our purpose and further complicates the situation. The trick is to define a system in which all the aspects of your management concern are included with no major links (i.e. flows of energy and matter) excluded. It should also be kept in mind that there are bound to be outside influences (if we did not we would be contradicting the premise behind our work) and that we can always lower or raise the resolution level to define a 'larger' or 'smaller' system, if the situation so dictates. "The focus of the systems approach is on providing a better picture of the network of subsystems and interrelated parts which go together to form a complex whole."19

The system which we have defined at a given resolution level is part of the environment (that set of all systems other than the one in which we are interested). Within the system there are subsystems; that is parts of the whole displaying a certain richness of intercommunication. For our purposes the lowest level of detail to be considered are the objects of both the system and subsystem as we are only interested in their relationships.

The system displays certain basic behavioural characteristics. Whether a system is real or conceptual (in our case it is not only real but living) it has a structure which undergoes internal changes over time and may as well experience irreversible changes in time. The reason is that all systems operate in time which is irreversible. A second pehavioural characteristic is that all systems are flow systems for the flow of energy and/or matter make up the relationships that are the heart of any system.

${ }^{19}$ Richard A. Johnson et al. , The Theory and Management of systems. (San Francisco: McGraw-Hill, 1973) p. 6. 
The Law of Requisite Variety is also essential to an understanding of modes in which systems operate and thereby can be managed. It states that to manage a system of given variety we must match it with a controlling system of requisite variety. The basis for this comes from the measurement of the 'largeness' of a system denoted by the term, variety.

In summary, the concepts to be noted and employed in dealing with systems management are:

1. definition of the system at a given resolution level.

2. consideration of the objects of the system keeping in mind their behavioural characteristics, that is flow, linkages and time.

3. all aspects of the system must be considered and managed (Iaw of Requisite Variety).

This approach encompasses 'general systems theory' whose development of a systematic framework deals with the world as an integrated heirarchy of organizations (ecosystems) and general relationships.

A whole which functions as a whole by virtue of the interdependence of its parts is called a system, and the method which aims at discovering how this is brought about in the widest variety of systems has been called general systems theory. General systems theory seeks to classify systems by the way their components are organized (interrelated) and to derive 'laws', typical patterns of behaviour, for the different classes of systems singled out by the taxonomy. 20

\section{plication of the systems outlook}

As stated in the section dealing with 'Management Strategy', water resources were going to be the focus of our systems management in the coastal zone. Based on the management objective, that is resolving present and future conflicts of utilization, we must now define the resolution level to be employed. The level decided upon includes all 
aspects of water utilization particular to the coastal zone (such as water supply, sewage disposal, industrial usage, water space usage, transportation, fishing and recreational activities) since it is these activities that cause the conflicts. In other words, management of the whole water environment.

Given the resolution level, the problem of mobility, and the inclusion of as much of the system as possible; we can now turn to a spatial description based on what has been presented.

The management strategy established earlier in this paper (i.e. the management of water) achieves its objective when the spatial unit found to be most frequently incorporated to date in land management is the river drainage basin or watershed.

The ecological effects of river basin development projects range from the immediate, very specific and readily predictable impacts to the less specific, less easily discerned, long term and possibly unforseeable impacts. 21

Man's culture has been intimately tied to the constraints and opportunities of the watershed which represents an area drained by a stream and its tributaries. It is bounded by a divide, whose elevation separates it from adjacent watersheds (a closed system). Thus from a geographic viewpoint the watershed forms a convenient unit for the consideration of the processes determining the state of the environment. The watershed has been cited as having the following advantages:

1. it is a natural unit suitable for intensive study of nutrient cycling at the ecosystem level

2. it provides a means of studying the interrelationships between the objects of the system and the various cycles and energy flows in a single system (the basic approach to ecology)

21 Raymond F. Dasmann et al., Ecological Principles for Economic Development. (London: John Wiley and Sons, 1973) p. 183. 
3. testing is possible of the effects of various land-management practices or pollutants in a natural system.

These advantages greatly enhance future investigation and research essential to any management program.

Further investigation does however point out two faults in the use of the watershed concept. These are related to their shape and size (hierarchy), but may be easily overcome. The shape of a drainage basin is determined by the effects of lithology and geologic structure. The dendritic type of drainage pattern common to Canada leads us to ask the following question. What happens to the interbasin area (in terms of management control) between the mouths of rivers emptying into the sea? This can be answered in one of two ways. Either the area is included with one of the drainage basins based on some other functional aspect (social-economic criteria) or incorporated with the two or more basins that form a management unit. What about the size of the drainage basin? Here again the 'situation' comes into play; the only criteria to be satisfied is that the watershed be acceptable to administrative capabilities.

The drainage basin has been presented as a viable spatial ecosystem that might be implemented to form the boundaries of the coastal zone management unit on land. What about the seaward boundary? After all, a gigantic one-way flow of elements moving from the earth and atmosphere into the ocean exists between the two areas. Figure 5 illustrates the general relationship between mineral resources, industry, agriculture, human population and the sea. A possible answer lies in the consideration of the coastal ocean ecosystem as it would have similar advantages of management as did the watershed, afforded to it by the systems approach. 


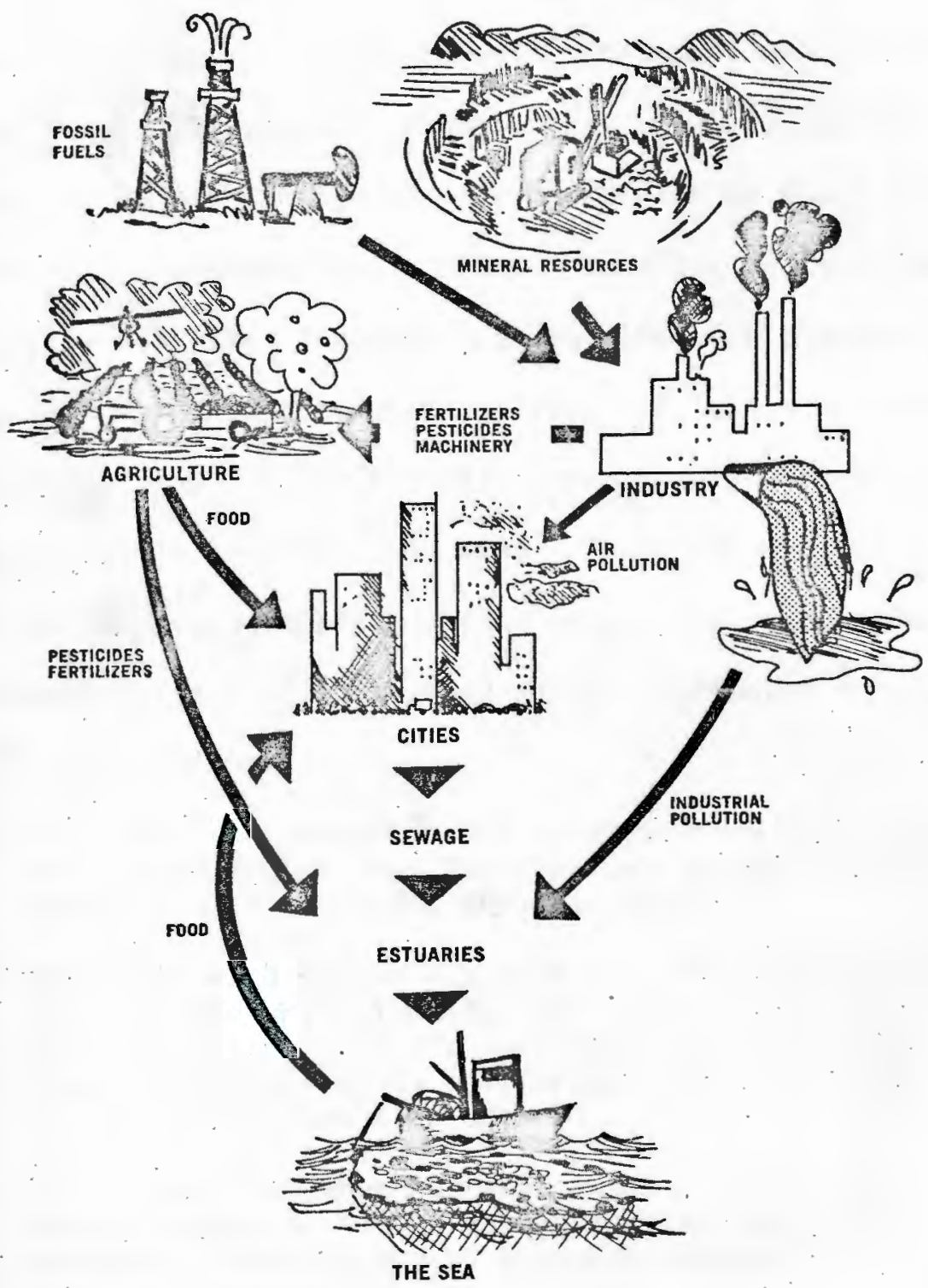

Fig. 5--Land-sea interrelationships (after Institute of Ecology, 1971) 
Why the coastal ocean? Geographically speaking, the coastal ocean overlying the continental shelf comprises a small part of the world ocean (12.5\%). The continental slope marks not only the topographical and structural edge of the continent, but also serves as the boundary between relatively shallow water covering the shelf and the great depth of the true oceans (Figure 3). Functionally, as land dwellers, man is most likely to see and use the coastal ocean; for in these highly productive and adjacent waters man has found supplies of food, new energy resources, disposal sites for municipal and industrial wastes, as well as conditions suitable for recreation, shipping, and many other uses. Above all physical and biological characteristics assert that the coastal ocean is a viable ecosystem. These characteristics are the result of the land/sea interface and it only. For example, the high nutrient content of the coastal ocean can be attributed to a number of factors. 22

1. the upwelling process draws nutrient-rich waters from the dark ocean depths into the shallower depths penetrated by sunlight (i.e. into the euphotic zone);

2. tidal and wind-driven currents over the relatively shallow water of the shelf increase the transfer of nutrients from deep to shallow. At the same time the shallowness of the zone itself results in more rapid recycling of nutrients than is possible in the deep ocean;

3. the strong discharge of fresh water into the sea from large rivers brings about the entrainment of deep water to the surface, in much the same manner as the upwelling process; and

4. river systems, both large and small, pump still other kinds of nutrients and trace elements into the sea from the lands which they drain.

${ }^{22}$ K. S. Ketchum, "Biological Considerations of Fisheries in Canadian Coastal Zones" Coastal Zone (Proceedings of Seminar held at Bedford Institute, Dartmouth, 1972) p. 118. 
The offshoots of these physical processes are biological eco-

systems. Coastal species of fish such as cod represent these ecosystems as they migrate throughout the coastal ocean but never leave such a favourable habitat.

In summation, based upon the acknowledgement of cod stocks as a form of water resource, we can accept their spatial range--the coastal ocean--as a viable ecosystem worthy of being a determinant of scope. 23 It is further possible to combine both the coastal and river systems into a larger coastal zone concept as subscribed to by the Coastal zone Workshop and others.

It is difficult to avoid a definition which encompasses less than the entire continental margin, namely, the region between the hightide mark and the base of the continental slope. Further, when we consider that not only marine species but also anadromous species (the salmons) play a very important role in the fisheries of the coastal zone, we are tempted to include the drainage systems of all rivers emptying into the sea, and indeed, so they should be, for in their own right they make significant biological and physicalchemical contributions to the general ecology of the shelf and slope. 24

${ }^{23}$ The systems approach as utilized in this paper involves the determination of scope which is only a part of an overall managerial style. Due to limitations of space, time, and purpose; the operations (I use this in its broadest sense) of this style are not pursued. For further reference to this see Ranney water quality Management--An Analysis of Institutional Patterns which discusses some of the administrative-political implications of a systems approach in contrast to the existing regulatory approach to water management.

${ }^{24}$ K. S. Ketchum, "Biological Considerations of Fisheries in Canadian Coastal Zones" Coastal Zone (Proceedings of Seminar held at Bedford Institute, Dartmouth, 1972) p. 117. 


\section{LEGAL-POLITICAL CONSIDERATIONS}

The systems approach to the management of water resources as presented in Chapter 2 is $1 /$ a way of thinking, 2/ a method or technique of analysis, and 3/ a managerial style. It comes about as a result of the application and subsequent adoption of the systems principles basic to the ecosystem reality of nature. Implicit in this approach is recognition that maintenance of the environment and the various systems comprising that environment depends upon the consistency of man-made standards, laws and boundaries with regard to the natural setting. The task to which we now turn is whether this new institutional alternative, as spatially defined by ecological considerations (systems approach) utilizing watersheds and the coastal ocean, has the administrative authority to act in Atlantic Canada? If not, is there the legal authority to seek the additional statutes and legal changes as needed; and will either satisfy the Law of Requisite Variety?

In this chapter acknowledgment of the man-made 'situation' is achieved through a review of the two spheres of jurisdiction covering the ecological description of the coastal zone, the domestic and international regimes. These laws, like ecosystems, also display spatial attributes responsive to scope delineation. It should be noted that in dealing with domestic jurisdiction we become specifically oriented to the case study of one country (Canada) in contrast to the ecological outlook which is applicable to most situations. The approach we will take, deals firstly with who holds the authority and/or possible 
alternatives as to how the legal-political regime might work. This will be followed by an evaluation of present--and/or speculation on future-enabling legislation given the present or alternative legal-political regime previously discussed.

\section{Jurisdictional Authority--Domestic}

Who has jurisdictional control and how the legal-political regime works is influenced to an important extent by the constitution. In order to illustrate this role of constitution let us look at the Canadian 'situation'. Canada as a federal nation divides all its primary governmental powers between the federal and provincial levels of government as dictated in the British North American Act.

Due to the scope and the complexity of environmental problems and the time at which the distribution of these powers occurred, it is not surprising to find difficulty in determining the federal and provincial governments responsibility in environmental management (Table 1). One of the chief reasons for this inability to place in two lists the respective governmental functions are the several complicating factors in the constitution (British North American Act) which can cause a function that would be federal in some circumstances to be provincial in others and vice versa. There are five of these complicating factors that can have the effect of changing the jurisdictional responsibility. 25 The first of these is the extreme generality of some of the language used in the British North American Act to describe federal and provincial powers. This means that some problems can fall within the urisdiction of both levels of government. The federal government's

${ }^{25}$ W. R. Lederman, "Concurrent Operation of Federal-Provincial Law" McGili Law Journal. 
ENVIRONMENTAL PROBLEMS

LIQUID WASTES

SOLID WASTES

GASEOUS WASTES

RADIOACTIVE WASTES

NOISE POLLUTION

VISUAL POLLUTION

WATER SUPPLY

NATURAL HAZARDS
AREAL SCALE OF PROBLEMS

SUPRA

PROVIN- PROVIN-

RURAL URBAN CIAL CIAL

$\begin{array}{cccccc}X & X & X & X & X & X \\ X & X & X & & X\end{array}$

$\begin{array}{lllll}X & X & X & X\end{array}$

$\begin{array}{lllll}\mathrm{X} & \mathrm{X} & \mathrm{X} & \mathrm{X}\end{array}$

$\mathrm{X} \quad \mathrm{X}$

$\mathrm{X}$

$\mathrm{X}$

X X

$\mathrm{X}$

X

X $\quad X$

X

X X

X

X X

X $\mathrm{X}$

$\mathrm{X}$

*from C. I. Jackson, The Spatial Dimension of Environmental Management in Canada, p.6 
power in such cases may be regarded as the more significant. That is, when jurisdiction does overlap both governments are free to deal with the matter, but if the legislations are inconsistent with each other the provincial government accedes to the federal legislation to the extent of the inconsistency.

The ability to delegate powers is the second complicating factor. It is possible in some cases for either the federal or provincial government to delegate to one another a function or power normally within their respective jurisdiction. Problems would occur when coastal zone management authorities transcending provincial boundaries would encounter different holders of power in identical areas of concern. A delegation of power has occurred.

A third complicating factor is interjurisdictional immunity. Simply stated, it means that although one government may have the power to make laws on a certain subject, there are instances when those laws are not applicable to the same activities carried out under the legislative control of another level of government. For instance some types of provincial law are applicable to the federal Crown and its enterprises while others are not. It usually depends on the individual case as occurs in the example that follows. Provincial laws relating to garbage disposal are applicable to airport authorities even though airports are under federal jurisdiction, but provincial air pollution abatement laws cannot be applied against the smoke from a docked ship otherwise under the province's jurisdiction.

The fourth complicating factor is the fact that the constitutional jurisdiction over a certain problem varies according to the solution sought to be applied to the problem. In any given situation, the federal level of government could play any one of three roles in 
pollution control:

A. Research, publication and other purely advisory roles.

B. Granting financial assistance for pollution abatement projects and programs.

C. Passing direct legislation on pollution.

In the first case the federal government's role is undeniable but in the second case the right is less clear although most authors seem to favour a strong federal spending power. As for the third case, parliament's power to pass laws relating directly to pollution is a matter of considerable doubt.

The fifth and final complicating factor to be considered deals with Canada's northern territories. These areas are outside the boundaries of the provinces, therefore the Canadian parliament in addition to its normal powers has the same jurisdictional powers in this region as does the provincial governments in their own realms. These five complicating factors make the formulation of environmental policies for a management program a tough task when one considers such a large subject area transcending the legislative powers of two levels of government.

Due to this federal nature of government in Canada, we have to look at the enabling legislation of both the federal and provincial governments. The federal government has enacted a number of pieces of legislation having a direct bearing on water management problems of the coastal zone. These include:

1. The Canada Water Act

2. The Canada Shipping Act

3. The Fisheries Act

4. The Navigable Waters Protection Act

5. The Northern Inland Waters Act

6. The Oil and Gas Production and Conservation Act

7. The Territorial Lands Act 
8. The National Harbours Board Act

9. The Animal Contagious Disease Act

10. The National Parks Act

11. The Migratory Birds Convention Act

12. The Criminal Code

13. The Income Tax Act

14. The Boundary Waters Treaty of 1909

15. The International Rivers Improvement Act

16. The Provincial Income Tax Legislation

A review of these Acts finds that the Canada Water Act, the Canada Shipping Act, the Fisheries Act, the Navigable Waters Protection Act, the National Harbours Board Act, and the International Rivers Improvements Act are of particular concern to our study, due to their association with water management problems.

The main federal agency responsible for water pollution control is the Department of the Environment. The two pieces of enabling legislation it has to work with are the Canada Water and Fisheries Acts.

The purpose of the Canada water Act, enacted in 1970, is to provide for the management of the water resources of Canada, including research, data collection, planning and implementation of programs relating to the conservation, development, and utilization of water resources. The Act is divided into four sections, three of which relate to our area of concern.

1. Comprehensive Water Resource Management

2. Water Quality Management

3. General Section on Powers of Inspection, Offences, and the Establishment of Advisory Committees.

Of primary importance to this study are the following points found within the first two sections.

The Act enables the Federal and Provincial governments to tackle the problem of water pollution jointly on a broad front through a water quality management agency. 
In the case of (a) any waters, other than federal waters, the water quality management of which has become a matter of urgent national concern, or (b) any federal waters, the Minister may, with the approval of the Governor in Council, from time to time enter into agreements with one or more provincial governments having an interest in the water quality management thereof, designating those waters as a water quality management area, providing for water quality management programs in respect thereof and authorizing the Minister jointly with such one or more provincial governments, to procure the incorporation of a corporation..., as a water quality management agency to plan, initiate and carry out, in conjunction with the Minister and such provincial government or governments, programs...26

secondly, the government recognizes the systems nature of the environment.

...or in any place under any conditions where such waste or any other waste that results from the deposit of such waste may enter any such waters. 27

Thirdly, the Act recognizes the different 'situations' that exist

throughout Canada. ...having regard to the distinctive geography of Canada and the
character of water as a natural resource...28

And finally, that the joint agencies composed of different members

"appointed by the Minister and the provincial government or governments that are parties to the agreement" are responsible to the public they serve.

... and taking into account views expressed at public hearings and otherwise by persons likely to be affected by implementation of the plans, ...29

If no agreement is reached between the Federal government and one or more Provincial governments, the Federal government may proceed on its own in response to matters of urgent national concern.

${ }^{26}$ Statutes of Canada, 1970, Canada Water Act, C.5 (1st Supp.), S.9. 27 Ibid.

28 Ibid.

${ }^{29}$ Ibid. 
The Fisheries Act is very pertinent in that it prohibits persons from depositing or permitting the deposit of waste of any type in any waters frequented by fish or in any place under any conditions where such waste may enter such waters. 'Waste' under the Act is defined as any substance that, if added to any waters would degrade or alter the quality of these waters to an extent that is detrimental to their use by man or by any animal, fish or plant that is useful to man. Many authors have suggested that the comprehensiveness of this Act, as backed by the British North American Act, is the mainstay from which all Federal water pollution legislation may be deemed constitutional.

A second federal agency having control over the use of coastal zone waters is the Department of Transport. Its enabling legislation is the Canada Shipping Act, the Navigable Waters Protection Act, and the National Harbours Board Act. Why are these Acts so relevant?

The Canada Shipping Act with its amendments to 1968 regulates the shipping industry in Canadian territorial waters and special zones. It provides for Oil Pollution Prevention Regulations in Canadian waters as well as non-Canadian waters within 50 miles of shore. Anti-pollution amendments have also been added, but the $50 \mathrm{mile}$ zone remains a major drawback for coverage of the coastal ocean.

The Navigable Waters Protection Act contains a number of provisions concerning disposal of solid wastes or other materials in navigable waters which might hinder navigation. This becomes extremely important when navigable waters are taken as "every body of water in Canada that can be navigated or, perhaps made navigable..."

The Harbours Boards established in Canada's major harbours, under the National Harbours Board Act, are capable of enforcing provisions restricting anyone within the harbour confines from draining or 
discharging into the water anything which causes a nuisance, endangers life or health or damages property. This Act gives to the federal government the power to work on water problems in one of our major areas of conflict whose management powers lie primarily in the hands of the provincial government.

The International Rivers Improvements Act allows the federal government to implement river improvement activities with transboundary ramifications.

The importance of the three preceding Acts might not be realized until a point is reached where the federal government should have to go it alone without provincial co-operation.

In summary it might be said that the federal Acts pertaining to water management issues provide an array of enacting power given the systems and encompassing nature of water. Constitutional impediments to the establishment of a Federal presence, generally under provincial control, have been circumvented by passing regulations in areas of clear Federal jurisdiction with the intent of providing a spin-off effect. "It is hoped that with the passage of such legislation as the Canada water Act, a much fiṛmer consolidation of efforts towards tackling water problems will result, and that this in turn could lead to similar legislation in other aspects of resource management." 30

Our attention now turns to enabling legislation passed by the provincial governments of Atlantic Canada. In Newfoundland the Department of Provincial Affairs and Environment has the primary responsibility for water management in the province. The statutes that have been

${ }^{30}$ E. Roy Tinney and J. G. Michael Parkes "Enhancing the Quality of the Environment: Current Federal Legislation and Programs" Habitat (Vol. XIII, No. $5 \& 6,1970$ ) p. 23. 
passed in relation to this area of concern include:

1. The Department of Provincial Affairs and Environment Act, 1973

2. The Department of Health Act, 1965

3. The Waters Protection Act, 1964

4. The Sanitation of Ponds Regulations, 1966

5. The Wildlife Act

6. The Crown Lands Act

7. The Nuisances and Municipal Regulations Act

8. The Local Government Act

9. The Pesticides Control Act, 1970

The Act of prime importance to our study is the Department of Provincial Affairs and Environment Act, which gives to the Minister powers and the duty to supervise, control and direct all matters relating to the protection and enhancement of the quality of the natural environment, including water. This control includes all surface, ground, and shore waters originating within the jurisdiction of the province. A serious limitation to the fairly comprehensive and far ranging series of statutes involved with water resources is the exemption of several major areas of water usage given to power commissions and new industries by water user rights.

The primary responsibility for water pollution control in Nova Scotia is vested in the Department of Environment's Water Branch by means of the Environmental Pollution Control Act and the Water Act. The Department exerts control and general supervision of $1 /$ the use of all surface, ground, and shore waters; $2 /$ the allocation of the use of water; 3/ pollution originating within the jurisdiction of the Province; and 4/ alteration of the natural features of any water course or lake and the natural movement of water therein. ${ }^{31}$ Pollution under the Water Act takes the following definition:

${ }^{31}$ Statutes of Nova Scotia, 1967, C.335, S.12; am.1968, C.64, S.6; 1970, C. 77, S. 5 . 
any alteration of the physical, chemical, biological, or aesthetic properties of the waters of the Province, including change of the temperature, taste or odour of the waters, or the addition of any liquid, solid, radioactive, gaseous or other substance to the waters or the removal of such substances from the waters, which will render or is likely to render the waters harmful or less useful for domestic, municipal, industrial, agricultural, recreational or other lawful uses, or for animals, birds or acquatic life. 32

In New Brunswick, water pollution control is the function of the New Brunswick Water Authority operating under the Department of Fisheries and Environment. The Authority exerts the same jurisdiction and power as does its counterpart in Nova Scotia with the same definition of pollution. 33

The Prince Edward Island Environmental Control Commission was vested responsibility for water pollution control by means of the Environmental Control Commission Act. The Commission shall exercise exclusive control of $1 /$ the use of all surface, ground and shore waters, 2/ the allocation of the use of waters, 3/ pollution originating within the jurisdiction of the Province, and 4/ alteration of the natural features of any water course or lake and the natural movement of the water therein;... 34 pollution in the Act is taken as any "alteration or variation of the physical, chemical, biological, or aesthetic properties of land, air or water which results, or which may result from any act or omission over which the Legislative Assembly of Prince Edward Island has jurisdiction." 35

A quick overview of the aforementioned statutes seems to provide

${ }^{32}$ Statutes of Nova Scotia, 1967, C.335, S.I; am.1968, C.64, S.I; 1970, C. 77, S.1.

${ }^{33}$ Ibid, Statutes of New Brunswick, 1960-61, C.19, S.4.

${ }^{34}$ Statutes of Prince Edward Island, 1971, C.33, S.15.

${ }^{35}$ Ibid, S.2. 
the various concerned governments the authority to act, but such a response is only piecemeal at its best, as management of the coastal zone breaks down with the mobility of water as it flows from one area of jurisdiction to another.

To satisfy requisite variety, let us review the roles the levels of government should play in the future in order that we might propose recommendations whereby the federal nature of constitutional responsibility may be overcome.

The first step is to take a look at this federal system. In Canada we have combined parliamentary government on the British model with a federal division of powers and responsibilities shared between the Parliament of Canada and the Parliament of the ten provinces. Due to this constitutional basis, today's complexities become even greater till the point is reached where co-operative federalism is the answer. W. R. Lederman in an article entitled "Cooperative Federalism; Constitutional Revision and Parliamentary Government in Canada" makes the following statement in response to such urgent social issues as pollution and environmental degradation.

My proposal is that we should simply consolidate these two processes (the issues of constitutional revision and the regular processes of government) into one process. In the federal-provincial meetings and conferences that would then constitute one process, prime ministers, ministers, and senior officials, in their various meetings, should first consider what ought to be done by intergovernmental agreements, under the existing constitution to deal with urgent social problems..., that involve both levels of government. If satisfactory arrangements can be made for complementary action by the federal government and provincial governments on the basis of the respective existing powers and resources, this is agreed and they proceed. If not, and if it emerges that the trouble in one of these problem areas is that there are either uncertainties or deficiencies in the federal division of powers under the B.N.A. Act in this respect, then and only then does one consider a reference to the courts for clarification of the gray area, or outright amendment... 36

${ }^{36}$ W. R. Lederman, "Cooperative Federalism: Constitutional Revision and Parliamentary Government in Canada" queen's Quarterly. p. 8. 
The development of better institutions and practices comes in response to the failure of the federal and provincial governments alone to have the constitutional power to exercise complete control over coastal zone water resources. The problem lies not only in the delegation of authority; that is

A/ split between the federal and provincial levels as already discussed, and

B/ the splitting of authority within a government level, for example, the Department of Environment, Transport, and Energy, Mines and Resources (seabed mining operations and oildrilled are pollution offenders) within the Federal government;

but also in the "fact that the constitutional jurisdiction over a certain problem varies according to the solution to be applied to the problem." 37

From our previous review of enabling legislation we know that theoretically legislation exists that solves the problem of management of water utilization; but does it exist in respect to the implementation of better institutions and practices? It is the answer to this question to which we now turn.

The federal legislation most applicable and suited to this purpose is the Canada water Act which allows for the establishment of 'water quality management agencies' composed of different members "appointed by the Minister and the provincial government or governments that are parties to the agreement." Do comparable statutes exist within the provincial Acts of the provinces to allow for this administrative set-up?

The Department of Provincial Affairs and Environment Act of the Province of Newfoundland concurs with the federal legislation through ${ }^{37}$ Ibid, p. 
the establishment of "such boards, committees and councils as he (Lieutenant-Governor) deems necessary or desirable to assist and advise the Minister in carrying out the provisions of this Act." 38 whether this might include some sort of arrangement with the federal government has not yet been considered.

In Nova Scotia, the Water Resources Commission may "enter and carry out an agreement respecting any matter or purpose mentioned in the Canada Water Act with the...Government of Canada, or an agency mentioned in that Act." 39

The Water Act gives to the New Brunswick Water Authority similar authorization "to enter into agreements with Canada or any other government to provide for the planning, conducting and implementing or programs for the more efficient management of water resources." 40

In Prince Edward Island, the Environmental Control Commission is not given the outright permission to enter into provincial-federal cooperation as occurs in Nova Scotia and New Brunswick. The only statute that seems relevant to our purposes is the power "to co-operate with any public or private body or any person in any matter relating to the control of pollution." 41 .

In summary, all levels of government have substantial roles to play in managing the coastal zone--federal and provincial authorities by virtue of the British North American Act and municipal authorities through the powers assigned them by provincial legislatures. The almost

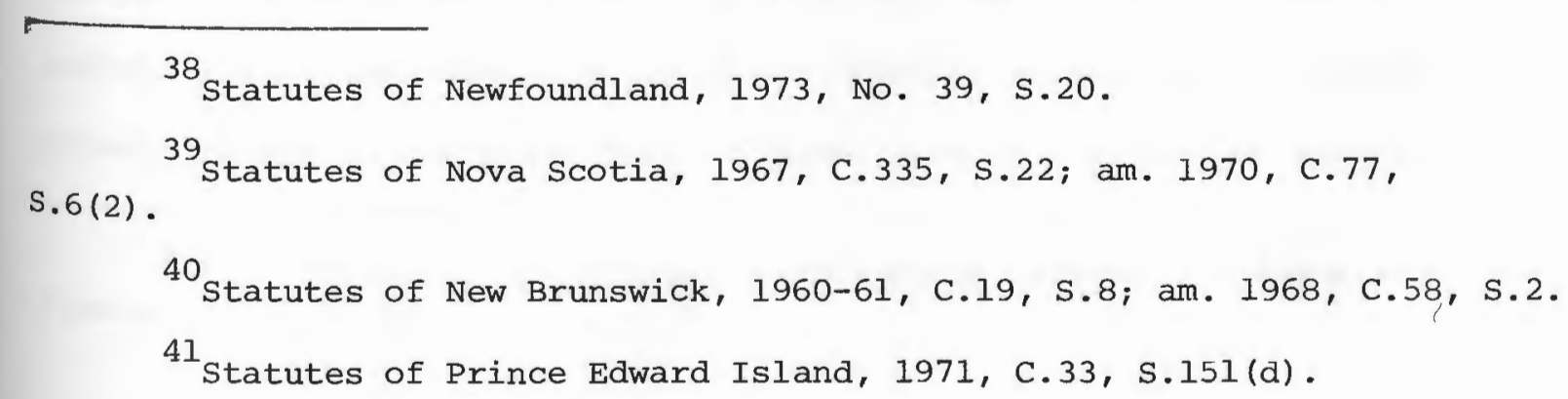


labyrinthine complexity is depicted in Table 2. This is widely acknowledged, but where the division between the jurisdictional spheres of each government lies is another matter. It can be concluded that federal constitutional realities are inadequate from a spatial point of view. A solution to this problem is co-operative federalism which from the review of enabling legislation is possible. Table 3 depicts the various statutes of the provincial and federal governments allowing for this co-operation.

If Canadians are to restore and enhance the quality of their environment concerted action at the international, national, provincial, and urban levels will be required. Some of the available strategies ...can be applied unilaterally by one government and some must be applied in cooperation with other governments.... This would appear to require among other things, a flexible framework that in some ways recognizes and is sensitive to the changing dimensions and dynamics of the problem. 42

The establishment of 'water quality management agencies' is compliant with the systems approach, which itself is sensitive to the changing dimensions and dynamics of the problem, and only requires the willingness of the part of each individual government to act.

Jurisdictional Authority--International

The previous survey failed to incorporate all of the coastal ocean, a very important component of the coastal zone in respect to Requisite Variety, as its inclusion brings us out of the domestic sphere of jurisdiction into the international realm. For international law, although primarily that body of rules governing the legal aspects of international relations, is nevertheless related to the interests of individuals of the coastal state as it directly or indirectly affects private rights to the point that it gives rise to issues; for example,

42 J. S. MacNeil, Environmental Management (Ottawa: Information Canada, 1971) p. 10. 
TABLE 2

POWERS

JURISDICTIONAL AREA

POLLUTION CONTROL

MINING

FORESTRY

FISHING \& WILDLIFE

AGRICULTURE

URBAN AREAS

TRANSPORTATION

ELECTRICAL ENERGY

MULTIPLE-USE WATER

MANAGEMENT

INTERNATIONAL

FISHERIES

CONTINENTAL SHELF

OCEAN POLLUTION

ABATEMENT
$\mathrm{X}$

$X$

$\mathrm{X}$
FEDERAL PROVINCIAL SHARED FEDERAL PROVINCIAL

X $\quad \mathrm{X}$

X $\quad X$

X $\quad$ X

$\mathrm{X}$

$\mathrm{X}$

$\mathrm{X}$

$\mathrm{X}$

X

$\mathrm{X}$

$X$

$\mathrm{X}$
PREDOMINANT POWER

X

X

$\mathrm{X}$

X 
TABLE 3

GOVERNMENT

FEDERAL

NEWFOUNDLAND

NOVA SCOTIA

PRINCE EDWARD ISLAND

NEW BRUNSWICK
ENABLING LEGISLATION

CANADA WATER ACT

PROVINCIAL AFFAIRS AND ENVIRONMENT ACT (qualified)

ENVIRONMENTAL POLLUTION CONTROL ACT

WATER ACT

ENVIRONMENTAL CONTROL COMMISSION ACT

WATER ACT 
oil slicks, over-exploitation of fishery stocks, and competition for space.

With this in mind, we must first take a look at the international framework within which a country such as Canada must function to ensure attainment of its objectives. In our case, the objective is that of effective environmental management of the water resource.

The international community is composed of states having the capacity to maintain external relations with other states in order to enjoy international personality. In order for these states to strive for better conditions outside their areas of jurisdiction they must present for ratification new international rules. Modern sources of these rules that may become international law include; treaties and international conventions; custom; general principles of law recognized by civilized nations; and judicial decisions and teachings.

Realizing that it has no right to exercise jurisdiction unless so deemed by rules of international custom or treaty law as achieved by the aforementioned sources, a state may turn to increased jurisdiction as offered within its boundaries to obtain its goals. With this in mind it may choose to extend the application of its laws and jurisdiction of its courts to persons, property, and actions outside its territorial boundaries by acquisition of said territory. As in the case of domestic law, this jurisdiction may be exclusive, concurrent, or limited.

Let us now turn to a brief review of territorial claims and jurisdiction in reference to ocean space.

"The problem of offshore boundaries is a complex one, involving major policy decisions on the allocation of marine areas, and specific delimitation procedures for laying down baselines along the shore and 
determining the outer limits of national control." 43 Gaps in the 1958 Geneva Conventions; differences of interpretation; and recent political actions such as international agreements and unilateral extensions of jurisdiction based upon 'special circumstances'; all account for the variety of national practices.

Two methods have emerged over the years as the common solutions to the management and control of the resources of the oceans.

The first and most widely used method is the extension of national sovereignity or jurisdiction over the coastal ocean by one of two means. These are:

1. extension of the territorial sea limits

2. continguous and economic zones

The extent of a state's territorial sea depends both on the breadth which is claimed and the type of baseline used in relation to its position from which the breadth is measured. The types of baselines we are speaking of include the normal baseline drawn along the low-water line and the straight baseline connecting prominent points along the coast. Complications arise in the use of the latter. Article 4 of the Convention on the Territorial sea and the Contiguous zone lays down certain guidelines for determining the adoption of a straight baseline regime and the delimiting of the individual baselines. These definitions have proven to be imprecise, however, thereby resulting in sweeping claims. The drawing of baselines, may enclose harbours, bays and historic waters, all of which are internal waters over which the state has unrestricted and uncontested sovereignty. As to the breadth of the territorial sea it varies throughout the world ranging from three miles to two humdred

43 Lewis M. Alexander, "The Nature of Offshore Boundaries" Canadian-U.S. Maritime Problems. (Kingston R. I.: Law of the Sea Institute, 1972) p. 56. 
miles. Recent developments seem to establish the growing popularity of the 12-mile territorial sea over the traditional 3-mile limit. The demise of the 1960 Geneva Conference has left this topic up in the air with the establishment of some norm to be attempted at the 1974-75 Law of the sea Conference. Sovereignty is only limited in the territorial sea by the right of innocent passage by foreign vessels.

The contiguous zone, provided for in the Convention on the Territorial sea and the Contiguous zone, is the exercising of certain forms of preventative or protective control beyond territorial limits by the coastal state. The most common is a contiguous zone reserved exclusively for fishermen of the coastal state. Economic or diffusion zones differ from the former in that their exclusiveness may involve exclusion of foreign vessels or prevention of carrying on normal activities associated with the high seas. "An Economic Zone is a proposal to establish an extensive maritime zone beyond 12-mile territorial limits within which the coastal state would exercise national jurisdiction, in the form of exclusive preferential rights and sole or special responsibility, with respect to the resources and related activities in the zone. "44

Unilateral claims of this nature are in most cases considered brash and decisive steps by the coastal state. They tend, however, to reflect the political and economic character of the coastal state. For example, zones established in the interests of resource availability and development concerns, experienced by the coastal state. A relationship that must weigh heavily in the consideration and implementation of such offshore claims of sovereignty.

${ }^{44}$ Douglas M. Johnston and Edgar Gold, The Economic Zone in the Law of the Sea: Survey, Analysis and Appraisal of Current Trends.

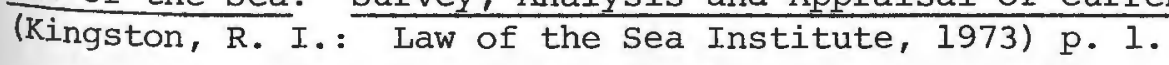


The types of control discussed so far are implemented by the coastal state alone; there is, however, a second method. This involves the entrance by the coastal state into multilateral agreements with other states in order to restrict activities occurring in offshore waters beyond national jurisdiction. To date most of these agreements have been associated with fishing activities and are characterized by the little support given to a coastal state's fishing industry against foreign fleets and as a rule have acted too late. This method is based on the doctrine that fish resources must be freely accessible to all, but joint action should be taken to ensure there is not overexploitation. In the case of pollution it is the use by all with joint action to ensure against degradation. The terms and powers of these agreements vary but in general they provide for consultative bodies which collect from the members information on their particular interest; provide projections of current trends; and recommend to governments restrictions that should be imposed. Reasons for the failure of such international organizations include:

1. scientific information on the state of affairs will always be imperfect and thereby gives a-government an excuse to delay action.

2. the problem of enforcement is overwhelming and often impossible.

3. conflicts of interest; that is coastal states, countries with established distant water fishing fleets, military interests, economic interests, and developing nations, reduce the possibilities of agreement.

Usually found within these agreements are three concepts. 'Historic Rights' gives a state which has traditionally fished in a given area, the right to continue usage. 'Preferential Rights' involve the implementation of fewer restrictions on the coastal state than on the foreign fishermen. The 'Principle of Abstension' "holds that in areas where 
states have built up and maintained the productivity of fishery stocks off foreign coasts through the expenditure of time and money and through restraints on their own fishermen, they should be entitled to prevent fishing by citizens of other nations (except those of the adjacent coastal state) if such fishing would result in a levelling off or decline in the yield for that area." 45

In summary it might be said, that given a set of objectives to be sought by the coastal state outside its jurisdictional sphere, two alternatives arise; either work through multilateral agreements within the existing international framework or act unilateraly with prescription to international institutions as desired.

Which alternative has Canada followed in regard to management of the coastal ocean waters? Prior to 1968, Canada's foreign policy was 'internationalistic' in approach based on the premise that the maintenance of international peace and security was the utmost goal of any country, and that this could only be achieved through the support of international organizations and law. The break between traditional Canadian policies and those of recent years was marked by an increased emphasis on Canadian interests and concern with Canada's well-being. It was felt that foreign policy should be an extension abroad of national policy with international goals regarded as relating primarily to the betterment of Canadians. The premise here was that national interests also imply a world order which is favourable to, or compatible with, the betterment of the Canadian domestic situation. At the same time it was felt that goals must be pursued along with a sense of international

${ }^{45}$ Lewis M. Alexander, Offshore Geography of Northwestern Europe. (Chicago: Rand McNally and Company, 1963) p. 99. 
responsibility. This new philosophy produced trends that have had significant implications for Canada's attitude and approach to international law. 46

First of all, the new foreign policy created a conceptual framework in which it became logical and necessary for problems of national interest to have solutions in foreign policy if applicable. This came out of a growing awareness that Canada with--the second longest coastline in the world; the second largest continental shelf; threatened fish stocks; vulnerable coastal and marine environments--would be faced with international developments that could have overwhelming relevance on the future well-being, and in some cases survival, of these attributes. Secondly, with this shift in objectives, Canada's attitudes changed as to the appropriate or most effective instruments for achieving these objectives. International law had come to be an instrument having bearing on national interests and therefore Canada must become far more active in the development of international law.

...We are, first of all, students of international law. We try to understand what are applicable rules and what are the practices of states. Second, we are practitioners seeking to find solutions to international problems through applying the existing rules and precedents. Third, we are our own advocates. We are our own cases in various informal ways. Fourth, we are often our own judges. We examine the other's case and we may accept or reject it. Fifth, we are legislators in various bodies of the United Nations, raising our voice and casting our votes in favour of rules which we believe to be just. 47

Canada through its representatives must also begin to work keenly for the adoption of stringent international rules in areas of national

${ }^{46}$ C. Dolphin and A. Gotlieb, "New Canadian Approaches to International Law" The American Journal of International Law. (Vol. 67, 1973).

$47 \mathrm{~J}$. G. Castel, International Law: Chiefly as Interpreted and Applied in Canada. (Toronto: University of Toronto Press, 1965) p. XXII. 
interest. In cases where the dependence on multilateral action to protect a national interest seems unrealistic a tendency emerges towards claiming national jurisdiction over these areas in order to reduce the vulnerability associated with external threats, witness the Arctic Waters Pollution Prevention Act. Last but not the least important of these trends, is that the action, whether in multilateral rule-making or in taking unilateral action, is a response to the threat or fear of consequences of activities based on new and advanced technology, for example, super-tankers.

The policy pattern of the Canadian government in regard to international affairs has been as follows: Policy formulation begins in international forums with a demand for acceptable and relevant international legal rules. If this fails, Canada is left with no alternative but to seek jurisdictional extensions to serve its purposes. These extensions may be coupled with a rejection of existing procedures for the international settlement of disputes. Finally Canada may seek to achieve an international region (for example, some sort of contiguous or economic zone based on predetermined motives) or international rules which embody the elements of enhanced international responsibility and extended national jurisdiction, thereby legitimizing the position taken. In summary what can be said about the international legal situation as it exists today? Generally, international law is not inclusive enough in spatial extent nor does it seek effective forms of enforcement when it does apply itself to marine management problems. International organizations have failed miserably in the case of enforcement. The increasing concern as denoted by the many Resolutions and Principles seems ironical when it is realized that the very same supporters of international actions are incapable of providing effective legislation-- 
not only the statutes themselves but the means to carry them out. The inability to act, whether intentional or otherwise, has resulted in the creeping seaward of national sovereignty. This itself comes in direct conflict with the establishment of an international regime of the high seas beyond the limits of national jurisdiction for the 'common heritage of mankind'. The establishment of responsive and acceptable norms and prevention of the furth breakdown of norms is the task confronting the forthcoming Law of the Sea Conference.

A general overview of foreign policy as practised by the Canadian government in recent years and the present international legal situation has been presented. We now turn to a discussion of the actions that have resulted from this policy in response to the international situation. This will be conveyed in respect to threats to territorial and 'ultraterritorial' resources of the oceans and seabed. Both types of threats are applicable to our definitional scope (ecological) of the coastal zone and its resources.

In respect to threats of territory, that is those being essentially physical damage to persons, property, and more broadly ecology; Canada's position has been first of all to work through appropriate international channels to establish rules of liability for such damage and procedures of redress. This explains Canada's compliance to a number of bilateral and multilateral conventions (because of the lack of international law), the most recent being the IMCO Convention on the Dumping of Wastes at Sea. These conventions as have been discussed have failed in certain rights in Canada's eyes, therefore Canada is prepared to act unilaterally by extending national jurisdiction beyond the 12-mile territorial sea. Such was the case of the Arctic Waters Pollution Prevention Act. 
At the same time however, Canada is willing to turn back to international machinery to incorporate any number of particular instruments (e. g. special agencies, treaties, conventions) which would constitute a "coherent, uniform and all-embracing treaty system". Such an instrument involves the implementation of coastal state responsibility. Principles reflecting this concept dealt with this approach from the international perspective.

These were:

A. the right of the coastal state to exercise special environmental preservation authority in areas of the sea adjacent to its territorial waters

B. the right of the coastal state to prohibit the entry of vessels into the waters under its environmental protection authority

c. The need for these rights of the coastal state to be exercised on the basis of internationally agreed rules and standards and subject to appropriate dispute-settlement procedures.

So in compliance with this approach, Canada at the Stockholm

Conference advocated a management system that would both greatly increase the nature and scope of a state's international responsibility for the effects of its environmental actions on others, and also grant recognition to the special authority of coastal states as a type of custodial authority delegated by the world community in areas adjacent to its territory. ${ }^{48}$ The statement read as follows:

Whereby a state is responsible for enforcing standards of prevention within certain zones at a certain distance from its coast has a number of merits.

1. Both the zones and the measures are directly related to the requirements of preventing the potential dangers arising from the particular activity. Interference with navigation is allowed only to the degree functionally necessary to prevent disaster.

${ }^{48}$ Working paper presented by Canada to Stockholm Conference (1972). 
2. It is preventive and does not require that states sit idly by until disasters occur.

3. It establishes zones of authority which are unlike zones of control beyond sovereign jurisdictional nonacquisitive. The coastal state does not acquire direct benefits in these zones but rather incurs responsibility to prevent certain harsm.

4. This decentralized arrangement takes due account of the ineffectiveness of international bodies to date, the ability to act.

In order to legitimize such an arrangement, an international organization must determine the appropriate zones and the nature of different activities to be included. Until such time, present Canadian actions have to be taken as claims over parts of the high seas.

The resources involved in the threats to 'ultra-territorial' areas are fisheries beyond the territorial sea and seabed resources (minerals and sedentary and nonsedentary fisheries). As in the previous case these threats are primarily the offshoot of technological development. There are, however, two complicating factors in this consideration. Firstly, the nature of Canadian fisheries is one of reliance on coastal stocks rather than distant water fisheries; therefore posing an even greater threat to the Canadian fishing industry, as it is these coastal stocks which are sought by foreign fishing fleets. Secondly, the threat is to resources that do not fall within the sovereign jurisdiction of the coastal state, although physically closer and often biologically dependent on the features of the coastal state. The Canadian response to the threat on fishing stocks was twofold. "One was to try to achieve international agreement on conservation measures and on self-restraint in fishing. The other was to extend one's jurisdiction to encompass as many of one's traditional fishing interests as possible." 49 The former

${ }^{49}$ C. Dolphin and A. Gotlieb, "New Canadian Approaches to International Law" The American Journal of International Law. (Vol. 67, 1973). 
response was borne out in the Working Paper on the Management of the Living Resources of the Sea submitted by Canada for international recognition. In it the functional approach was presented as the soundest basis for the rational management of living marine resources. This approach assumes such management as being a part of a broader scheme of management of the marine environment as a whole. The adoption of this functional approach to fisheries management must first differentiate between the various ecological groups (on the basis of distribution and migratory behaviour) of fish; that is sedentary, coastal, anadromous, and wide-ranging species. It is then felt that the coastal state has a special interest in and responsibility for the sedentary, coastal and anadromous species for purposes of conservation adjacent to its coast "and should have the authority required to manage those resources in a manner consistent with its special interest and responsibility, as well as preferential rights in the harvest of such resources." 50 The second response, extension of jurisdiction, leads us into a review of Canadian domestic actions (legislation of the Canadian Parliament). After the failure of efforts to endorse its six-plus-six formula which sought the eventual phasing-out of traditional foreign fisheries in Canadian coastal waters, the Canadian government enacted the Territorial sea and Fishing Zones Act in 1964. This Act proclaimed a 12-mile fishing zone around Canada's coast for the exclusive use of Canadian fishermen (far from a functional approach). In 1967 in response to Norway's lead, the drawing of straight baselines from headland to headland was implemented by the government to further increase the scope of this fishing zone.

${ }^{50}$ Canadian Working Paper on the Management of the Living Resources of the sea. 
In amendments to the Territorial sea and Fishing Zones Act during 1970 the 3-mile territorial sea was replaced by a 12-mile limit and fishery closure lines were drawn across the entrances to the strait of Belle Isle, the Bay of Fundy, and the Gulf of St. Lawrence.

In summary, Canadian foreign policy has been one of recognition of the special character of the coastal state while seeking remedies first through international channels then unilaterally if necessary. Where does our coastal zone management concept fit into this scheme of things in relation to threats to territorial waters and the "ultraterritorial' resources of coastal waters? Perhaps the best solution lies in the establishment of special zones at a certain distance from the coast which only entail a jurisdictional authority to prevent degradation and depletion of coastal waters and its resources. Of the traditional and including the following four freedoms of the sea, i.e. navigation, overflight, fishing and the laying of submarine cables, the least affected would be overflight and the laying of cables with navigation and fishing interfered with only to the degree functionally necessary to prevent environmental destruction. The seaward boundary for such a zone was not established; if it were based on the spatial extent of present day utilization, practices (i. e. in relation to economic zones, etc.), and ecosystem reality, the zone should extend to either the edge of the continental shelf or range of coastal species. Whichever is employed, it requires unilateral action on the part of the Canadian Government. 
IV. THE ECOLOGICAL-LEGAL CONCEPT AS APPLIED TO COASTAL ZONE MANAGEMENT AUTHORITY DELINEATION--CONCLUDING REMARKS

Synopsis

The purpose of this thesis was to identify strategies that governments might employ in order to respond to environmental problems that arose from the various utilizations made of the coastal zone and which required environmental management to rectify. The goal of such an environmental management program is the maximum sustained use of coastal resources consistent with the retention of the natural ecosystem and amenities of the coastal zone. The policies that would result from this goal were not further developed but the stipulation that neither the complete destruction of the natural environment nor complete prohibition of development and exploitation was forwarded. In other words, environmental management was seen as the answer to the problems of the coastal zone with symbiotic relationships as the objective to be achieved within the present status quo.

The strategy of our coastal zone management proposal was to seek the management of one resource thus providing a foundation from which eventual integrated management of the environment would stem. Water was chosen as that resource for many inherent reasons including its importance, management history, and character.

In the long run the problem of the coast, the development of its resources, the preservation of its qualities...all these are going to depend on the management and control of human activities which are land based. And how we use the land has a bearing on how we 
use the water, which in turn affects how we use the land. 51

The dynamic character of water led the author into what is

believed to be the most basic task in the implementation of resources management, namely the delineation of the management area. At this point, the American experience was drawn upon but to no avail in regards to criteria'for a standard procedure of coastal zone delineation.

Such criteria, it was then felt, must evolve from management philosophy and strategy. This dictated:

A. the realization that deterioration and destruction were the result of uncontrolled interactions between human activites and the natural environment.

B. the maintenance of the status quo through understanding of the 'situation' before the selection of the options of utilization were made (the management process).

This reasoning formed the basis for the selection of legal and ecological criteria.

Ecological considerations led to the application of two systems, the watershed and coastal ocean, in the delineation of the coastal zone.

Given the ecological scope, the applicability of the legal 'situation' was reviewed from two aspects; that is, domestically and internationally. Due to divided domestic jurisdiction (Table 2), integrated management was thought the answer provided "all jurisdictions, competences, and capabilities could be brought together for joint goal setting, planning and operation." ${ }^{52}$ This required co-operative federalism which given the enabling legislation, as depicted in Table 3, satisfied

${ }^{51}$ D. Brack, statement made at opening session of Maritime Coastal Zone Seminar (1973).

52 J. W. MacNeil, Environmental Management (Ottawa: Information Canada, 1971) p. 171 . 
spatial requirements. 53 Internationally, satisfaction of the spatial requirements given the 'situation' is not possible within present international legal norms, although future action was predicted based upon present trends in order to make a case.

It is this case to which we now turn as well as review the applicability of the considerations as they are applied.

Implementation in Atlantic Canada

It could be fairly stated that the future of the Atlantic Provinces is the future of their coastal zone. The land/sea interface represents a unique combination of physical and biological resources offering distinct economic advantages and social amenities for which there are no alternatives. 54

Of the two million people living in Atlantic Canada over $80 \%$ live within 10 miles of salt water. ${ }^{55}$ The concentration of people and activities increases yearly and no doubt the trend will continue.

Atlantic Canada can be thought of as a region where three zones of primary exploitation meet: "the Northern North Atlantic, a zone of coastal settlement marginal to waters heavily fished by international fleets; the continental sub-arctic, a zone of boreal forest exploitation dominated by international pulp and paper companies and dependent upon highly competitive world markets; and Appalachia, a zone of mineral exploitation involving metallic and non-metallic ores and fossil fuels highly dependent upon international financing and marketing." 56

${ }^{53}$ These requirements are a result of our systems approach forwarded in the ecological considerations made.

54 Department of Environment, A Proposal for a Coastal Resources Inventory and Mapping Program.

${ }^{55}$ Based on calculations of statistics from 1971 Census (statistics Canada).

${ }^{56}$ Alan G. Macpherson, ed., The Atlantic Provinces. (Toronto: University of Toronto Press, 1971) p. XI. 
In addition to this, recreational use increases yearly; a use that touches very closely to the ecological and aesthetic qualities of the environment.

The crux of the matter is as follows. While populations are low and so long as uses do not conflict severely with the environment, a laissez-faire policy of uncontrolled multiple-use is acceptable. However, as problens increase in relationship to the exponential increase of people and technology, serious strains are exerted on the coastal zone's ability to support these demands, which are not confined to one specific area due to the nature of various activities and/or to the activity scope. The location of these activities of man in Atlantic Canada are depicted on Map 1. Therefore this map serves as a notice of the 'situation' and ideally the scope of our coastal zone management should encompass the activity scope.

Presupposing the willingness on the part of the Provincial and Federal governments to implement a management program for the coastal zone; we must now draw upon the criteria and assumptions as evolved from knowledge of the ecological and legal 'situations' discussed. 57

${ }^{57}$ We have assumed both a willingness to act as well as a thorough knowledge of the situation. In the case of the latter; what is presented is sufficient for our purposes but a broader and more extensive data base is required as management unfolds. The intent to act is growing stronger as is evident from the following excerpt from the proceedings of the Maritimes Coastal Zone Seminar held in May of 1973.

"...but there is need for much greater co-operation, communications and teamwork, to use these resources more effectively in meeting the problem.

...To do so, however, requires the further development of love for the land, and a desire to work together to accomplish the desired ends.

Out of these concerns, the seminar offers the (following) recommendation.

That a Maritıme Coastal Zone Planning Committee jointly appointed by the Council of Maritime Premiers and the Federal Government: 
From ecology, a systems outlook based on the watershed and

coastal ocean was forwarded as determinants of scope. The watershed provides a physical configuration with landward and lateral boundaries. The coastal ocean, on the other hand, can only be a determinant of the seaward extent of management's scope as a lateral boundary is undefinable due to the mobility of water.

Based on the legal 'situation' as covered, the utilization of the watershed was felt feasible given the motivation to act and co-operate. The seaward boundaries were a different matter altogether as they involve speculation on our part. Such speculation allowed us to take the 200 meter isobath as the edge of Canada's territorial limits and thus the seaward extent of management. The lateral boundaries, from a legal point of view, are only definable where Atlantic Canada borders with the United states and Greenland. 58

The boundaries that arise out of the ecological and legal considerations are depicted on Map 2. Upon review of the map, it is realized that a discrepancy occurs with the seaward boundaries. Due to ease of definition, the ecological boundary (range of coastal species) was dropped in favour of the 200 meter isobath but the coastal ocean concept was still retained as most of it was retained within the delineated area. Otherwise, the range of coastal species would have to be first accepted in principle by other nations and then defined on the basis of

(a) assist provincial and federal governments to develop comprehensive coastal zone plans for each province, with regionally compatible goals;"

${ }^{58}$ Iateral boundaries between coastal states are defined upon the basis of the extension of lateral land boundaries seaward or median lines. At present there is a dispute between Canada and the United states about the Maine-Nova Scotia international boundary. 
a map co-ordinate system that would be more difficult to enforce and comply with.

There are a number of points that should be noted in reference to the scope of the coastal zone as depicted on Map 2. Firstly, it should be acknowledged that these boundaries are not the ideal solution as the coastal ocean may be easily influenced from outside. We can only hope that a buffer zone is created in regard to oceanic pollution and that time is being bought for the fishery stocks that require international management action. In essence, both are just stop-gap measures until an acceptable and enforceable Convention on Ocean Pollution and Management is ratified. Secondly, with respect to a new Convention, the narrowing of the scope could only serve to facilitate administration of the management program. Lastly, the extent of the landward boundary depends upon the resolution level chosen. In our case it was all river systems flowing into the coastal waters of Atlantic Canada with the exception of the St. Lawrence River.

Exclusion of the St. Lawrence can only lead to one's questioning of the validity and applicability of the concept.

\section{Applicability of the Concept}

The applicability of this concept to world conditions, it is felt, may be judged through the consideration of the following criteria. They are as follows:
A. Legal-political
B. Social-cultural
C. Ecological
D. Geographic
E. Functional

From a legal-political aspect the applicability will depend on the legal and administrative ability to act, government structure (one 
or a number of levels of government as exists in Canada), and the amount of cooperation possible between the various levels of government if so structured.

The social-cultural aspect is taken in two lights. Firstly, as the perspectives that a particular country's population has towards the state of the environment. Management must stem from the perception of a problem and a willingness to seek its solution. Secondly, it relates to demography, for where there is or is not human activity so is the need for management.

The crux of the matter from an ecological aspect is basically the utilization of criteria inconsistent with present day practices. On the other hand, however, a systems approach employing ecosystems is a natural reality and therefore basic to all areas of application.

Geographically, the applicability is associated with the size and nature of the watershed and the physical setting. The following problems can occur but are easily overcome without hurting the validity.

1. Large Rivers--Rivers the size of the St. Lawrence with watersheds in the hundreds of thousands of square miles are considered too large and unmanageable within the context of coastal zone management. Hopefully management of such a watershed by one or a number of authorities can account for an acceptable standard of outflow.

2. Islands and Peninsulas--Smallness of watersheds in conjunction with the physical setting dictates consideration of a functionally more acceptable management unit. Examples of such administrative units include Prince Edward Island and the Avalon (Newfoundland) Peninsula (Map 2).

3. Inter-jurisdictional Rivers--The watersheds of such rivers would have to be partially managed unless inter-governmental agreements are made.

4. Bathymetry--Where the 200 meter isobath extends inside internal waters (by legal description), closure lines might have to be employed. The drawing of such artifical lines was employed in the case of the Laurentain Channel (Map 2) which intersects the Gulf of st. Lawrence. 
Finally, the functional aspect relates to the manageability in respect to it being possible and realistic given the 'situation'. This aspect the author feels is the most critical in assessing the applicability and thus the validity of the delineation considerations.

In summary, as the 'situation' differs from area to area so will the applicability of our standard procedure concept for delineation. Its usefulness is assured, however, by being responsive to the 'situation'.

\section{Conclusion}

Ecological and legal criteria have been used to delineate the spatial extent of the coastal zone and its management units. The next step in the management process is the formation of an administrative framework responsive to the ecological and legal 'situation'. The mobility of water and federal-provincial representation (as called for in pertinent acts of both governments) are two issues to which the management program must be responsive. Given the 'situation' and the mobility of water, it was felt that the management of the Atlantic Coastal Zone could only be carried out through an Atlantic Region Coastal Zone Authority with a number of local Coastal Zone Authorities responsible to it and represented on it.. The Atlantic Coastal Zone Authority would:

1. set standards to be met by all local authorities in order to ensure base standards across the region

2. administrate the coastal ocean through regional policies, standards, and enforcement

3. act on regional issues such as nuclear power plant siting The local Coastal Zone Authority would handle most affairs in its area of jurisdiction (composed of one or a number of watersheds). Like the Atlantic Region Coastal zone Authority the local Authorities will be comprised of federal and provincial members plus local Coastal zone 
Authority representation.

The preceding administrative framework is most suited because of the ecological and legal criteria under consideration. This is not to say, however, that different conditions that may be spawned temporally and spatially, will not be recognized; management units must avoid becoming inflexible and static. The thesis began with the premise that the management process must be responsive to the 'situation'. 59 Therefore any rigidity in institutional boundaries must be avoided lest this premise be ignored throughout the program. In fact criteria which allow for future boundary changes should be designed.

Other criteria might also be employed for management unit design in combination with those already discussed. At the outset or as the management program develops demographic, utilization, and functional considerations should be used to finalize the spatial extent of initial management units. The spatial extent of population and the actual numbers of people within initial management units are two aspects of the demographic 'situation' that may be used to alter the original boundaries. Other valid criteria include the type and homogeneity of land use (i.e. forestry, agriculture, recreation, industrial, residential, and communications); and the interfunctional ties that exist, develop, or disappear overtime among these uses. The separability of land uses becomes an important criteria; management units boundaries could be altered because one area is primarily recreational while the other is urbanized (indus-

59 The ecological 'situation' was thought by the author to be something severely lacking as a focus in past management programs; henceforth, its incorporation from the outset must aid implementation later and must provide the core element around which adaptation of the management' unit occurs. 
trial and residential use). The latter are usually incompatible uses. On the other hand, interfunctional ties that might develop between a forested area and an industrial area that processes the former's raw materials could call for inclusion of both areas in one management unit. In summary, we began with a management objective and a focus. Our criteria (ecological and legal) created the initial unit within which the objective might be realized, recognizing the 'situation'. Because the 'situation' will undoubtedly change, so will our management objectives and focus, and therefore, so will the criteria to be considered and the units themselves. Delineation of the management unit by recognition of the 'situation' through various criteria is still and undoubtedly the first step towards successful management practices. It is, after all, our purpose to achieve a spatially founded unit that is most appropriate to present management objectives and ecolocial-legal considerations. We cannot, however, create rigid and inflexible units that will resist the future and the ecological, legal, and other changes that it will certainly affect the success or lack of success of present management objectives. 
Abbott, Richard D., ed. The Law of Environmenta1 Quality. Montrea1: Canadian Council of Resource Ministers, 1971

Alexander, Lewis M., ed. The Law of the Sea: Offshore Boundaries and Zones. The Ohio State University Press, 1967

- Offshore Geography of Northwestern Europe. Chicago: Rand McNa1ly and Company, 1963

- and Hawkins, Gordon R.S。, eds。, Canadian-U.S。 Maritime Problems. Kingston, R.I.: Law of the Sea Institute, 1971

Armstrong, J.M. and Bradley, Earl H. Jr., A Description and Analysis of Coasta 1 Zone and Shoreline Management Programs in the United States. Ann Arbor: University of Michigan Sea Grant Program, 1972

At1antic Development Board, Fisheries in the Atlantic Provinces. Ottawa: Queen's Printer, 1969

- Water Resources of the Atlantic Provinces. Ottawa: Queen's Printer, 1969

- Urban Centres in the Atlantic Provinces. Ottawa: Queen's Printer, 1969

Beckett, John A., Management Dynamics. New York: McGraw-Hil1, 1971

Black, W.A., The View from Water Street. Ottawa: Information Canada, 1973

Bloom, Arthur L。, The Surface af the Earth. Englewood Cliffs, N.J.: Prentice Ha11 Inc。, 1969

Brahtz, J.F. Peel, ed. Coasta1 Zone Management: Multiple Use with Conservation. New York: John Wiley and Sons Inc。, 1972

Caste1, J.G., Internationa1 Law: Chief1y as Interpreted and Applied in Canada. Toronto: University of Toronto Press, 1965

Canadian Council of Resource Ministers, The Administration of Water Resources in Canada. Montreal: Canadian Council of Resource Ministers, 1968

Chambers, M.J. and Nelson, J.G., eds。 Water. Toronto: Methuen, 1969

Chute, Robert M., Environmenta1 Insight. New York: Harper and Row, 1971 
Canadian Industries Limited, A Digest of Environmental Pollution Legislation in Canada. Vol I \& II Montreal: CIL, 1973

Clawson, Marion, Resources, Economic Development, and Environmental Quality. Guelph, Ontario: Centre for Resource Development, 1971

Commission on Marine Science, Engineering, and Resources, Our Nation and the Sea. Washington D.C.: U.S. Government Printing Office, 1969

Cox, George W., ed. Readings in Conservation Ecology. New York: Meredith Corporation, $\overline{1969}$

Cram, J.S., Water: Canadian Needs and Resources. Montreal: Harvest House, 1971

Chadwick, George, A Systems View of Planning. New York: Pergamon Press, 1972

Darling, F.F. and Milton, J.P., eds. 'Future Environments of North America. Garden City, New York: Natura1 History Press, 1966

Dashmann, Raymond F., Environmental Conservation. New York: John Wiley and Sons Inc., 1968

Department of Environment, Coastal Zone - Vol。 1 Selected Background Papers. Proceedings of a Seminar held at Bedford Institute of Oceanography, Dartmouth, Nova Scotia, March, 1972

- A Proposal for a Coastal Resources Inventory and Mapping Program for the Maritime Provinces and Newfoundland, 1973

Detwyler, Thomas R., ed. Man's Impact on the Environment. New York: McGrawHil1, 1971

Devany, J.W.; Derbis, E.; Seifeit, W.; and Wood, W.; Economic Factors in the Development of a Coastal Zone. Cambridge, Mass.: MIT Press, 1970

Dubois, Rene, So Human An Animal. New York: C. Scribner and Sons, 1968

Edey, Maitland A., The Northeast Coast. New York: Time Inc., 1972

Ehrlich, Paul R.; Holden, John P.; and Holm, Richard W., Man and the Ecosphere. San Francisco: W.H. Freeman and Company, 1971

Flawn, Peter T., Environmental Geology: Conservation, Land-Use Planning, and Resource Management. New York: Harper and Row, 1970

Hachey, H.B., Oceanography and Canadian Atlantic Waters. Ottawa: Queen's Printer, 1961

Hills, R. Jean, The Concept of System. Eugene, Oregon: University of Oregon Press, 1968 
Hite, James Co and Stepp, James M., eds。 Coasta1 Zone Resource Management. New York: Praeger Publicátions, 1971

Institute of Ecology, Man in the Living Environment. Madison: The University of Wisconsin Press, 1973

Johnson, Richard A.; Kast, Fremont E。; and Rosenzweig, James E., The Theory and Management of Systems. San Francisco: McGraw-Hi11, 1973

Johnston, D.M. and Gold, Edgar, The Economic Zone in the Law of the Sea: Survey, Analysis and Appraisal of Current Trends. Kingston, R.I.: Law of the Sea Institute, 1973

Judy, Richard W.; Ouellet, Lionel; and Sewe11, W.R。 Derrick, Water Management: Socia1 Science Priorities. Ottawa: Queen's Printer, 1969

Ketchum, Bostwick $H_{\bullet}$, ed. The Water's Edge. Cambridge: MIT Press, 1972

MacNei1, J.W., Environmental Management. Ottawa; Information Canada, 1971

Macpherson, Alan G., ed. The Atlantic Provinces. Toronto: University of Toronto Press, 1972

McHarg, Ian, Design with Nature. Garden City, N.J.: Doubleday and Company Inc., 1971

Morisawa, Marie, Streams: Their Dynamics and Morphology。 New York: McGraw-Hi11, 1968

Nova Scotia Resources Council et a1。 Maritime Coastal Zone Seminar. Sackville, N.B., 1973

Oda, Shigeru, The International Law of Ocean Development. Netherlands: A.W. Sijthoff International Publishing Co, 1972 .

Ranney, David C., Water Quality Management: An Analysis of Institutional Patterns. Madison, Wisconsin: University of Wisconsin Press, 1972

Smith, Robert Leo, The Ecology of Man: An Ecosystem Approach. New York: Harper and Row, 1972

- Ecology and Field Biology. New York: Harper and Row, 1966

Strah1er, Arthur N., Physical Geography (3rd ed.) New York: John Wiley and Sons Inc., 1969

Sub-Committee on Multiple Use, Towards Integrated Resource Management. Ottawa: Queen's Printer, 1970

Thewe11, Norman, The Effluent Society. London: Methuen and Co., 1971

Tucker, Edwin W., Legal Regulation of the Environment. St. Paul, Minn。: West Publishing Co., 1972 
Van Dyne, George M., ed. The Ecosystem Concept in Natural Resource Management. New York: Academic Press, 1969

Wagner, Richard $H_{0}$, Environment and Man : New York: W.W. Norton and Company Inc., 1971

White, Gilbert F., Strategies of American Water Management. Ann Arbor: University of Michigan Press, 1969

Articles

Alexander, Lewis M。 "Marine Regions of the United States" University of Rhode Island, 1969 (mimeographed)

Armstrong, John M. and Bradley, Ear1 H. Jr。, "Status of State Coasta1 Zone Management Programs" Marine Technology Society Journa1. (v.6 n.5), 7-16 and (v.6 n.6)

Beesley, J.A., "Rights and Responsibilities of Arctic Coastal States: The Canadian View." 1971 (mimeographed)

Berryhi11, Henry, "The Coastal Margin: Its Nature and Uses" Law and the Coastal Margin. Sea Grant Publication TAMU-W-70-00I

Bissel, Harold, "Coastal Zone Planning in California" A Seminar on Proposed Coasta1 Zone Management. Sea Grant Publication HUMSC-W-71-001

Brack, David M., "The Ocean Coasts of Canada" Canadian Geographical Journal (Vol. 87 No.4)

Canadian Delegation to the United Nations, "Working Paper on Preservation of the Marine Environment" 1972 (mimeographed)

Canadian Delegation to the United Nations, "Working Paper on Management of the Living Resources of the Sea" 1972 (mimeographed)

Dolphin, C. and Gotlieb A。, "New Canadian Approaches to International Law" The American Journal of Internationa1 Law. Vo1。67, 1973

Harrison, R.J., "Constitutional Jurisdiction for Water Legislation in Canada" Proceedings of the Peace-Athabaska Delta Symposium, Edmonton, Alberta: University of Alberta, 1971

Hart, William J., "Techniques for Management of Coastal Zone Resources" Proceedings of the Second New England Coastal Zone Management Conference, 1971, p. 60-76

Inman, D.L。 and Nordstrom, C.E., "On the Tectonic and Morphologic Classification of Coasts" The Journal of Geology, 1971 
Jackson, C.I., The Spatial Dimensions of Envirommental Management in Canada, Unpublished, 1970

Kennedy, V.S. et a1., "Regional Planning and the Cheaspeake Bay Environment: An Ecological Approach" Proceedings of the First New England Coastal Zone Management Conference, 1970, p. 47-74

Knight, H. Gary, "Proposed Systems of Coastal Zone Management: An Interim Analysis" Sea Grant Publication LSU-R-70-001

Laird, Beverly L. et a1., "Documents Related to the Management of the Coastal Zone: An Annotated Bibliography", Virginia Institute of Marine Sciences, 1972 (mimeographed)

Lederman, W.R., "Concurrent Operation of Federa1-Provincial Law" McGil1 Law Journá1

- "Cooperative Federalism: Constitutional Revision and Parliamentry Government in Canada" Queen's Quarterly

Lynch, M.P., "Coasta1 Zone Inventory" Sea Grant Publication

McNamara, Thomas F., "An Environmental Management Challenge" Sea Grant Publication HUMSC-N-70-001

Miloy, Leatha F., "Summary of Law and the Coastal Margin" Sea Grant Publication TAMU-W-70-001

Ozere, S.V., "Needed Sea Law To Protect Sea Resources" Canadiàn Geographical. Journa1. Ottawa: Royal Canadian Geographical Society (Vol. 87 N.3)

Pfannstiel, Daniel C., "A Perspective of Coastal Land Utilization" Sea Grant Publication TAMU-Z-70-017

Ray, Carleton, "Ecology, Law, and the 'Marine Revolution'" Biological Conservation. (Vo1.3 No. 1)

Saville, Thorndike Jr., "Research Needs In the Coastal Zone" Proceedings of the Second New England Coastal Zone Management Conference, 1971 p. $50-59$

Teeters, Robert D. Jr., "Present and Future Demands Upon the Coastal Zone" Seminar on the Multiple-Use of the Coastal Zone. p. 77-95

Tinney, E. Roy and Parkes, J.G. Michael, "Enhancing the Quality of the Environment: Current Federal Legis1ation and Programs" Habitat Vol. XIII No. 5 \& 6,1970 